\title{
Lipids in pharmaceutical and cosmetic preparations
}

\author{
By Antonio M. Rabasco Alvarez and María Luisa González Rodríguez
}

\author{
Facultad de Farmacia, Universidad de Sevilla, C/ P. García González, s/n. \\ 41012 - Sevilla, SPAIN.
}

\section{RESUMEN}

\section{Lípidos en preparaciones farmacéuticas y cosméticas}

En el presente trabajo se ha llevado a cabo una revisión sobre las aplicaciones de los lípidos en el campo famacéutico.

En un primer apartado, se describieron los diferentes lípidos utilizados como excipientes en cosmética y medicina. En este sentido, se utilizan muchos aceites vegetales, como el aceite de almendra, albaricoque, aguacate, borraja, café, cártamo, etc.; a partir de fuente animal, pueden emplearse como excipientes en formulaciones cosméticas los aceites de pescados y de aves. También se utilizan con este propósito las grasas y las ceras. Así mismo se revisan los fosfolípidos empleados en cosmética y en diagnosis, que actúan como vehículos transportadores de sustancias activas, como los liposomas.

Finalmente, se llevó a cabo un estudio de los lípidos, en función de su actividad biológica, como sustancias activas que forman parte de la elaboración de formulaciones cosméticas, farmacéuticas o suplementos nutricionales. Los carotenoides, retinoides y tocoferoles son usados por sus propiedades antioxidantes, importantes para la salud y la medicina preventiva.

PALABRAS-CLAVE: Cosmética - Excipientes - Lípidos Medicina - Suplemento nutricional.

\section{SUMMARY}

\section{Lipids in pharmaceutical and cosmetic} preparations

In this paper, a review of the applications of lipids in the pharmaceutical field has been reported.

In a first stage, different lipids used as excipients in cosmetics and medicines have been described. Many vegetable oils are used in this sense: almond oil, apricot oil, avocado oil, borage oil, coffee oil, safflower oil, etc.; from de animal source, fish oil and bird oil can be employed as excipients in cosmetical formulations. Fats and waxes may be also used for this purpose. A broad range of phospholipids are suitable for use in cosmetics, pharmaceuticals and diagnosis. These substances are used as vehicle for therapeutic substances, such as liposomes.

Finally, a study of lipids, as a function of their biological activity, as active substances for the elaboration of pharmaceuticals, cosmetics or nutritional supplements, was carried out. Carotenoids, retinoids, tocopherols are used for their antioxidant properties, that are important to health and diagnostic medicine.

KEY-WORDS: Cosmetic - Excipients - Lipids - Medicine - Nutricional supplement.

\section{INTRODUCTION}

The word «lipid» comes from the Greek word lipos, meaning fat greasy to the touch. Lipids are diverse group of organic compounds found in plants, animal and micro-organisms. They comprise one of the three large classes of foods and, with proteins and carbohydrates, are components of all living cells.

According with Bloor's concept, lipids can be defined as one of the major classes of biological substances constituting a cell. Some lipids are completely insoluble in the water of the protoplasm while dispersing themselves throughout in the form of tiny droplets in other cases as certain chemical groups attached to the lipids apparently bind them to the water molecules. Lipids like lecithin and cephalin, which are soluble in water and fats, serve a vital role in the cell by binding water-soluble compounds such as proteins to lipid-soluble substances.

In lipid droplets energy storage is more efficient because the molecules are concentrated into a small area. Also, lipids are better than carbohydrates for energy storage because the carbons on the acyl-chains of the lipids are in a highly reduced state, which maximises the energy per mole given off when those carbons are oxidised into carbon dioxide and water. Carbohydrate carbons are already partially oxidised, and therefore give off less energy.

However, for decades, progress in lipid chemistry lagged well behind that in other major biological substances, most notably carbohydrates and proteins. Two principal reasons have been pointed out. First, it was more simple and easy to device laboratory methods for handling carbohydrates and proteins; fats and substances closely associated with them were generally amorphous, and they were distressingly difficult to separate into individual components by methods commonly employed in organic chemistry in the early part of this century. Second, the principal lipid substances, mainly triacylglicerols in fats and oils, were considered to be relatively inert biologically, serving primarily for storage of energy that could be drawn upon as needed. Thus, in general, there was little interest in research to discover the properties, structures, biosynthetic pathways, biological utilisation, and functions of triacylglicerols, and of 
qualitatively less abundant or even unusual lipids (Lundberg, 1984).

Lipids discussed in detail in this study are triglycerides and their derivatives, fatty acids and their derivatives, natural plant and animal waxes, and phospholipids. Also mentioned are sphingolipids, carotenoids, tocopherols and other types of lipids.

\section{LIPID FUNCTIONS}

Lipids possess important functions at very different facets. They are indispensable for all the living beings, since they exercise important plastic, energy and metabolic functions. They have also, numerous applications in Nutrition and Dietary, Food Science, cosmeticals, pharmaceuticals, paints and varnishes, detergents, etc.

The Food and Agriculture Organisation of the United Nations (FAO) and the World Health Organisation (WHO) have listed five of the most important functions of dietary fats as follows: as a source of energy (obtaining primarily carbon dioxide and water in their ultimate conversion), for cell structure and membrane functions (lecithin is an important structural component of the cell membrane, where it maintains continuity between the water and lipids phases inside and outside the cell), as a source of essential fatty acids for cell structures and prostaglandin synthesis, as a vehicle for oil-soluble vitamins (A, D, E and $K$ ) and for control of blood lipids.

The role of fats in relation to cholesterol metabolism and cardiovascular disease (atherosclerosis, coronary thrombosis and cerebral haemorrhage) has a long and controversial history. Many questions still remain about the roles that fats play in these phenomena in relation to the structures of dietary fatty acids (Leaf, 1996). There have been many recent developments relating to complexes where lipids and proteins are held together by forces of the van der Waal type, as in lipoproteins. It now appears that there is a good correlation between the incidence of cardiovascular disease and the blood levels of high density lipoproteins (HDL), or the ratio of high density and low density lipoproteins (HDL:LDL) (Siess, 1999; Weber, 1999).

From another viewpoint, lipids were once the primary sources of aliphatic carbon compounds used by industry. With the arrival of petroleum, the consumption of lipids declined in most industrial applications, although obviously they still retain their strong position in foods and feeds.

Today, market forces, regulations, and concerns about the environment once again bring lipid materials to the fore, as an alternative to petrochemicals (Shimada, 1999). At the very same time, new technologies have come along to create new and modified lipids and to introduce new properties and performance characteristics. New vegetable oils are near commercial introduction.

Since lipids appear to be on the verge of renaissance, it will be critical to assess the market opportunities for the new technologies and products and to understand the forces for change in the years ahead (Rotheim, 1997).

\section{CLASSIFICATION}

Because very little was known until after the turn of the 20th century about the vast number of different classes of lipid compounds, no serious attempts had been made to classify lipids.

Lipids can be classified in many ways, due to their different composition, nature and origin. According with Bloor's classification, lipids can be divided in: simple lipids, compound lipids and derived lipids. Individual characteristics are not discussed in this section because they are well known. In tables I and II, the most important lipids and fatty acids are collected.

The structure of simple lipids are like chain-like molecules consisting of hydrogen, carbon and oxygen alcohol known as glycerol (glycerine) and the fatty acids. They are combined to make up these simple acids. They release more energy when burned in the cell than any of the other substances in the cell. However, they are not easily burned as sugars, hence they are stored in cells as reserve sources of energy found in abundance in the cells as fatty tissues.

Compound lipids yield «other substances» upon hydrolysis besides alcohol and fatty acids.

Derived lipids include steroids, fat-soluble vitamins, prostaglandins, etc.

\section{LIPIDS AS EXCIPIENTS IN COSMETICS AND MEDICINES}

In this section, we are going to describe the most useful lipid substances that are used as excipients in pharmaceutical and cosmetical preparations. In many cases they are used indistinctly in cosmetic formulations and in pharmaceutical products. For that reason, it is difficult to establish a clear division between them.

\subsection{Simple lipids}

\subsubsection{Triglycerides}

Triglycerides are esters of trihydroxy alcohols with three fatty acid molecules. They are the principal components of oils and fats. 
Table I

Classification of lipids

\begin{tabular}{|c|c|c|c|c|}
\hline \multirow{4}{*}{ Simple lipids } & \multirow[t]{3}{*}{ Triglycerides } & \multirow[t]{2}{*}{ Oils } & Vegetable oils & $\begin{array}{l}\text { Almond, apricot, avocado, borage, canola, } \\
\text { castor, coffee, corn, evening primrose, } \\
\text { macadamia, olive, safflower, sesame, } \\
\text { soybean, walnut, wheat germ }\end{array}$ \\
\hline & & & Animal oils & Black Sea dogfish, emu, sardine, shark liver \\
\hline & & Fats & \multicolumn{2}{|c|}{ Cocoa, coconut, palm, shea butter } \\
\hline & Waxes & & Bees wax, jojoba, lanolin, spermaceti \\
\hline \multirow{12}{*}{ Compound lipids } & \multirow{8}{*}{ Phospholipids } & \multicolumn{3}{|c|}{$\begin{array}{l}\text { 1,2-Dimyristoyl-sn-glycero-3-phosphate (DMPA) } \\
\text { 1,2-Dipalmitoyl-sn-glycero-3-phosphate (DPPA) } \\
\text { 1,2-Distearoyl-sn-glycero-3-phosphate (DSPA) }\end{array}$} \\
\hline & & Phosphatidyl glycerols & \multicolumn{2}{|c|}{$\begin{array}{l}\text { 1,2-Dimyristoyl-sn-glycero-3-phosphoglycerol (DMPG) } \\
\text { 1,2-Dipalmitoyl-sn-glycero-3-phosphoglycerol (DPPG) } \\
\text { 1,2-Distearoyl-sn-glycero-3-phosphoglycerol (DSPG) } \\
\text { 1,Palmitoyl-2-oleoyl-sn-glycero-3-phosphoglycerol (POPG) }\end{array}$} \\
\hline & & \multicolumn{2}{|l|}{ Diphosphatidyl glycerols } & \\
\hline & & \multicolumn{3}{|c|}{$\begin{array}{l}\text { 1,2-Dimyristoyl-sn-glycero-3-phosphoethanolamine (DMPE) } \\
\text { 1,2-Dipalmitoyl-sn-glycero-3-phosphoethanolamine (DPPE) } \\
\text { 1,2-Distearoyl-sn-glycero-3-phosphoethanolamine (DSPE) } \\
\text { 1,2-Dioleoyl-sn-glycero-3-phosphoethanolamine(DOPE) }\end{array}$} \\
\hline & & \multicolumn{3}{|c|}{$\begin{array}{l}\text { 1,2-Dilauroyl-sn-glycero-3-phosphocholine (DLPC) } \\
\text { 1,2-Dimyristoyl-sn-glycero-3-phosphocholine (DMPC) } \\
\text { 1,2-Dipalmitoyl-sn-glycero-3-phosphocholine (DPPC) } \\
\text { 1,2-Distearoyl-sn-glycero-3-phosphocholine (DSPC) } \\
\text { 1,2-Dioleoyl-sn-glycero-3-phosphocholine (DOPC) } \\
\text { 1-Palmitoyl-2-oleoyl-sn-glycero-3-phosphocholine (POPC) }\end{array}$} \\
\hline & & \multicolumn{3}{|l|}{ Phosphatidyl serines } \\
\hline & & \multicolumn{3}{|l|}{ Phosphatidyl inositols } \\
\hline & & \multicolumn{2}{|l|}{ Phosphone analogs } & \\
\hline & \multirow[t]{2}{*}{ Sphingolipids } & Sphingophospholipids & Sphingomielins & $\begin{array}{l}\text { Egg sphingomyelin (ESM) } \\
\mathrm{N} \text {-palmitoyl sphingomyelin (C16SM) } \\
\mathrm{N} \text {-stearoyl sphingomielin (C18SM) }\end{array}$ \\
\hline & & Sphingoglycolipids & $\begin{array}{l}\text { Cerebrosides } \\
\text { Gangliosides }\end{array}$ & \\
\hline & Glycolipids & & & \\
\hline & Sulfolipids & Sulfogalactolipids & & \\
\hline \multirow[b]{2}{*}{ Derived lipids } & \multirow[b]{2}{*}{ Steroids } & Sterols and sterol esters & \multicolumn{2}{|c|}{ Cholesterol, cholesterolstearate } \\
\hline & & $\begin{array}{l}\text { Sterylglycosides and } \\
\text { acylsterylglycosides }\end{array}$ & & \\
\hline
\end{tabular}




\begin{tabular}{|c|c|c|c|}
\hline \multirow{7}{*}{ Derived lipids } & \multirow[b]{2}{*}{ Steroids } & Sterol sulfates & \\
\hline & & $\begin{array}{l}\text { Bile acids and their } \\
\text { conjugates }\end{array}$ & \\
\hline & \multirow{4}{*}{$\begin{array}{l}\text { Fat-soluble } \\
\text { vitamins }\end{array}$} & A & $\begin{array}{l}\text { Carotenoids } \\
\text { Retinol }\end{array}$ \\
\hline & & $\mathrm{D}$ & \\
\hline & & $\mathrm{E}$ & \\
\hline & & $\mathrm{K}$ & Tocopherols \\
\hline & Prostaglandins & \multicolumn{2}{|c|}{$\mathrm{PGA}_{2}, \mathrm{PGB}_{2}, \mathrm{PGE}_{2}, \mathrm{PGF}_{1 \alpha}, 6$-keto-PGF ${ }_{1 \alpha}, \mathrm{PGD}_{2}, \mathrm{PGH}_{2}, \mathrm{PGI}_{2}, \mathrm{U}-46619,11-\beta-\mathrm{PGF}_{2 \alpha}$} \\
\hline
\end{tabular}

Table II

\section{Classification of fatty acids}

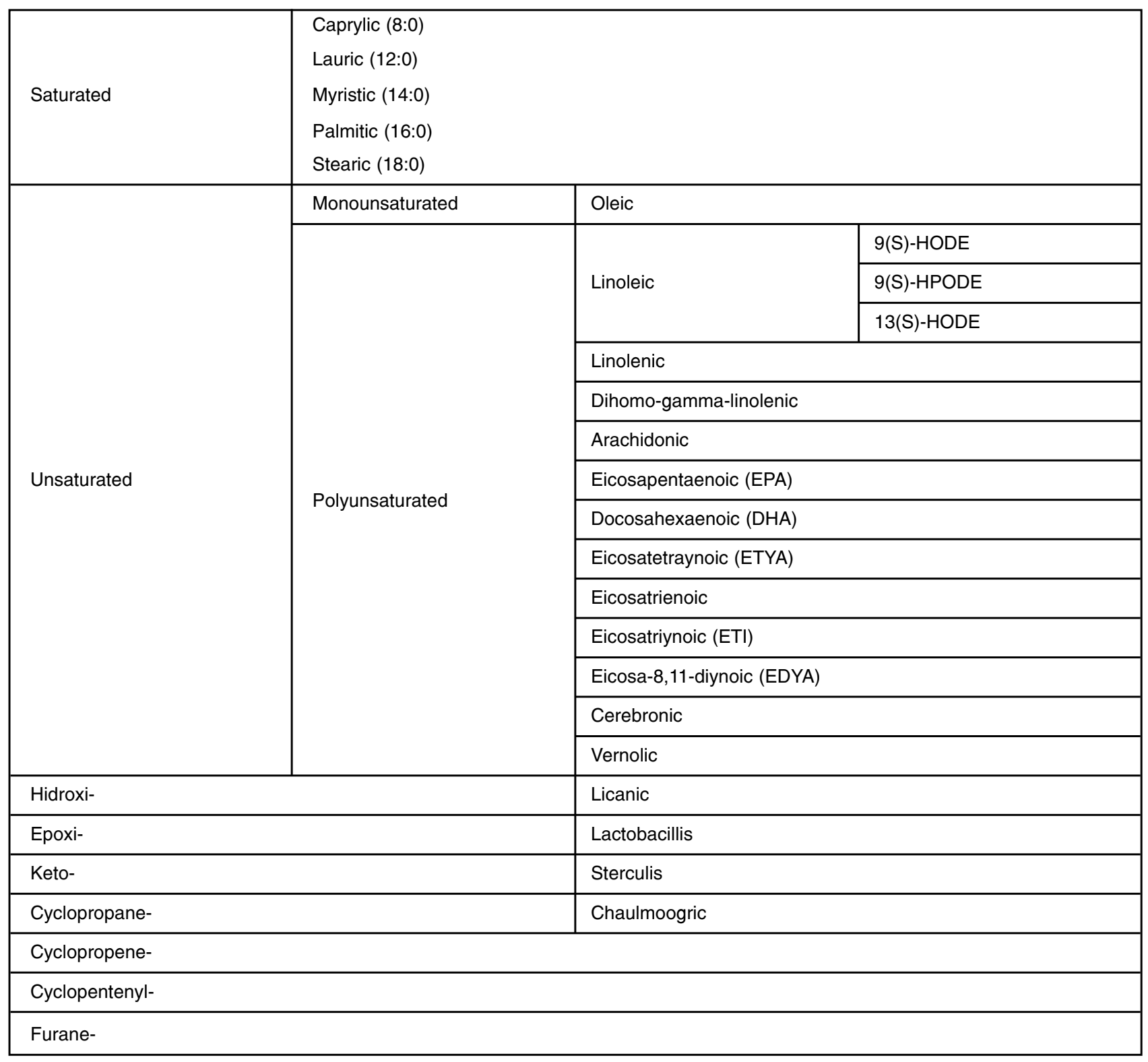


Fats and oils are water-insoluble substances of plant or animal origin that consist predominantly of triglycerides. Those that are solid or semisolid at room temperature are normally called fats, while those that are liquid under the same conditions are called oils.

The European Union, the United States, and the People's Republic of China are the largest markets, together accounting for over $40 \%$ of world consumption; India, the former USSR, Brazil, and Japan account for another $20 \%$ of the total; other regions and countries make up the remainder.

The European Union countries, which together account for more than $16 \%$ of global consumption, are the world's largest consumers of fats and oils, requiring net imports of $15-20 \%$ to meet demand. Animal fats, soybean oil and rapeseed oil are the three dominant products, accounting for over 50\% of the EU market. This region is the world's largest producer of olive oil, supplying $77 \%$ of the market.

The United States has about $13 \%$ of global demand; soybean oil and inedible tallow and grease together constituted more than $60 \%$ of U.S. consumption. Growth in overall U.S. demand for the next five years is expected to be modest, although product substitution of those oils with low levels of saturated fats (e.g., canola oil, sunflower oil, olive oil) will continue to displace oils with high levels of saturated fat (e.g., palm oil and coconut oil) in the edible vegetable oil market. Nonfood markets accounted for $27 \%$ of total U.S. demand in 1992, with animal feeds, fatty acids, soap, drying oil industries, plastics and resins, and lubricants and greases the main nonfood applications (Zuanich, 1998).

\subsubsection{Oils}

They are liquid products obtained by different techniques from the fruit of some vegetables or some animal organs. They are principally constituted by triglycerides; they also contain another lypophilic substances in low proportions, such as fatty alcohols, hydrocarbures, fatty acids, vitamins, phytosterols, etc. These last components determine in many cases their cosmetical and pharmaceutical activity.

\section{Vegetable oils}

The principal constituents of vegetable oils are esters of glycerol and fatty acids along with partially glyceridic material such as lecithin and substances such as tocopherol. Their composition will vary according to the species and the use will depend especially upon the variety, type and proportion of fatty acids.

ALMOND OL: Sweet almond nut oil is the mechanically expressed oil from the ripe fruit of the tree Prunus dulcis, which is a member of the Rose family. It is characterized as a pale yellow, clear oil having a very mild, sweet, nutty odor and taste. Prized by aromatherapists as one of the best carrier oils, it is used in cosmetic preparations as a moisturizer and is reported as such excessively dry skin, sunburn, wind burn and under certain conditions as an antioxidant to preserve other natural ingredients. This oil is a good emollient because of its high unsaturated fatty acid distribution. It can cause inestability problems in cosmetical preparations. It is used in infant formulations, lip balms, creams and it makes a pleasant soap. This oil is also used as an ingredient for preparing microcapsules (Esquisábel, 1997).

APRICOT OIL: Apricot oil is the mechanically expressed oil from the ripe fruit of the tree Prunus armeniaca, which is a member of the Rose family. This oil is characterized as a pale yellow, clear oil having a very mild odor and taste. It has a high percentaje of oleic acid (Girgis, 1998). This is a light, soft oil often used alone in massage. It is also used in toilet soaps, lip balms and creams.

AvocADO OIL: It is the centrifuge extracted oil from the fruit of the tree, Persea americana (also classified as Persea gratissima), which is a member of the Lauraceae family. The avocado is native to the tropical regions of Mexico and Central America. Avocado oil is clear, and predominately monounsaturated giving it excellent oxidative stability. It is light and nontacky with quick penetration characteristics. The odor and flavor of this oil are of a very pleasant, faint nutlike tone. It is used as emollient, protector and regenerator. All these actions seem to be as a consequence of its unsaponifiable matter. It is possible to find avocado oil in expensive creams and lotions, baby soap and shaving soap.

BORAGE OIL: It is derived from the seed of borage (Borage officinalis). Borage oil is sought after for its content in unsaturated fatty acids. This oil also contains 1 to $2 \%$ unsaponifiables.In capsules, borage oil is often recommended to treat skin and what's this mean? problems: it is used to prevent ageing and wrinkles, to fight dehydration and the loss of skin elasticity (gamma-linolenic acid plays the essential role). Borage oil has regenerative, firming and restructuring properties. It is thus a worthwhile ingredient in products for dry, damaged or tired skin and in products for dry or permed hair. It can be used in any cosmetic product as an active principle or as a carrier in the oily phase, without any proportion limit (Tolleson, 1993; Henz, 1999).

CASTOR OIL: It is a fixed oil obtained from the seeds of Ricinum communis and contains $80 \%$ ricinoleic acid triglyceride (Wilson, 1998). It is used as an occlusive skin conditioner and solvent in products such as lipsticks, eye and face makeup and nail polish. Lipsticks dermatitis related to castor oil were reported (Andersen, 1984; Wakelin, 1996). 
This oil is classified as an oleaginous vehicle and is present in some topical pharmaceuticals, intramuscular injectables and solid oral dosage forms (Montousse, 1999). Its high viscosity makes difficult its use in some cosmeticals, but through ethoxylation become non ionic surfactant having good solubilizing properties for oils. Polyethoxylated castor oils are used in cosmetics as a perfume, in alcoholic vehicles as a volatile oil solubilizer, and in hand lotions as a substitute for castor oil. PEG hydrogenated castor oils are used in aftershave lotions, cleansing products, skin fresheners, colognes, hair tonics and other cosmetics with alcoholic vehicles. Polyethoxylated castor oil (Cremophor ${ }^{\circledR}$ ) is used as an emulsifier and solubilizer in pharmaceuticals containing volatile oils, fat-soluble vitamins and other hydrophobic substances. Hydrogenated castor oil is used in some solid oral dosage forms and topical creams (Smolinske, 1992; del Arco, 1997).

COFFEE OIL: It is derived from the seeds (beans) of species of trees belonging to the Rubiaceae family, genus Coffea. Of the more than 30 species, only 3 are of important commercial value: the Arabian (Coffea arabica), the Robusta (Coffea canephora), and the Liberian (Coffee liberica). Coffee oil is derived from exclusively the Coffea arabica species, which is considered by most to be the finest species of coffee in the world. Coffee oil has demonstrated excellent skin feel properties due to its fatty acid profile character (Tisnes, 1992). However, even more interesting is its ability to block solar radiation from the 280 to 320 nanometer range which causes erythema, but at the same time allows radiation $(320-400 \mathrm{~nm}$ ) to pass which tans the skin. This function is believed to be caused by free unsaponifiable materials naturally inherent in the oil known as caffestol and kahweol, and monoesters of caffestol and kahweol (Pons, 1995).

CORN OIL: It is obtained from the seeds of Zea mais by extraction with solvent. This oil possesses a high content in unsaturated fatty acids and it has been very used for the production of bar soaps (Delaveau, 1971; Pons, 1995; Hasson-El-Mallah, 1999).

MACADAMIA NUT OIL: This oil is the expeller pressed oil from the ripe fruit of the tree Macadamia ternifolia. It is characterized as a pale yellow, clear oil having a very mild odor and taste. Macadamia nut oil is one of the highest plant derived sources of palmitoleic acid, which protects the cell lipids against peroxidation. This essential fatty acid is mostly found in fish oils, in such high quantities is rarely found in vegetable oils. Given its high content in essential fatty acids, macadamia nut oil has restructuring properties: it strengthens the skin lipidic barrier and thus improves the skin moisturization. It has emollient and regenerative properties and is an adequate skin conditioner. Due to these properties, it is a recommended ingredient in nourishing shampoos for dry hair, moisturizing creams for dry skin and baby skin, restructuring creams for around the eyes for mature skin, hand creams and lip balms (Ako, 1995).

OLIVE OIL: This oil is the fixed oil expressed from the fruits of the tree Olea europaea. The major constituents are triolein, tripalmitin, trilinolein, tristearate, monostearate, triarachidin, squalene, $\beta$-sitosterol and tocopherol.Olive oil is used as a solvent and skin and hair conditioner in cosmetics. Types of products include shampoos and hair conditioners, cleansing products, topical creams and lotions and suntan products (Smolinske, 1992). It is a potent fatty acid penetration enhancer (Loftsson, 1997). Olive oil is an oleaginous excipient used in oral, topical and parenteral solutions.

SAFFLOWER OIL: It is the expeller pressed oil from the seed of the plant Carthamus tinctorius, which is classified by many as the world's most ancient crop. It is characterized as a pale yellow, clear oil having a very mild, nutty odor and taste. Regular Safflower oil (linoleic safflower oil) approximately contains $75-80 \%$ linoleic acid. This high percentage makes difficult its utilization in some preparations. So, it is possible to treat it to convert linoleic acid to oleic acid (oleic safflower oil), that demonstrates excellent oxidative stability in cosmetic formulations. Safflower is very rich in essential fatty acids which are important for the integrity of the skin tissues. These essential fatty acids bring to the cell membrane essential structuring components which are not synthesized by the skin and constitute a reserve in which the skin cells draw its nourishment. It is absorbed rapidly in the skin epithelium where the nourishing benefits of polyunsaturated triglycerides can be utilized. Safflower oil is used on the skin as a replacement for mineral oil which is reported to desolve vitamin $A$ in the skin.

SESAME OIL: It is the expeller pressed oil from the seed of the plant Sesamum indicum, which is a member of the Pedaliaceae family. This oil is characterized as a pale yellow, clear oil having a very mild, nutty odor and taste. It has been produced for thousands of years and is considered the "queen" of oils because of its stability and lack of impurities. Sesame oil contains powerful, natural antioxidants (sesamin, sesamol, sesamolin, and phytosterol) which give the oil very good oxidative stability. Sesame oil is very stable and resistant to oxydation and it can bestow this property on other cosmetic components thus making it a natural preservative. It has pronounced regenerative action due to its high unsaponifiable content. Effective in countering ill effects on the skin resulting from aging, sesame oil has been reported to have healing effects on certain skin conditions such as eczema, seborrheia, psoriasis and sunburn. Sesame oil is used as a solvent and skin and hair conditioner in cosmetics. 
Types of products include makeup foundations, lipsticks, eye makeup and hand and body creams and lotions. It is present in some parenteral pharmaceutical products (Ten Wolde, 1997; Esquisábel, 1997) and there are also several oral capsules, emulsions, tablets and topical creams containing this excipient (Smolinske, 1992). Alveolar carcinoma was reported in an elderly man who used sesame oil continously to lubricate his tracheal cannula (Maesen, 1985). It has also been reported hipersensibility to sesame oil in foods and cosmetics (Pecquet, 1998; Stern, 1998).

SOYBEAN OIL: Soybean oil is the refined fixed oil obtained from the seeds of Glycine soja. Constituents are primarily triglycerides of oleic, linoleic, linolenic and saturated acids. Soy protein residues are not consistently present in refined soybean oil. Less purified derivatives, such as some cold-pressed soybean oils, may contain soybean proteins. This oil is used for its emollient properties in bath oils, shampoos and hair conditioners, cleansing products, creams and lotions, and suntan products. It is also used in pharmaceuticals (Asai, 1999). Intravenous fat emulsions used in parenteral nutrition (Intralipid ${ }^{\circledR}$ ) contain soybean oil, egg yolk phospholipids, glycerol and water for injection (Turco, 1987). Soybean oil oxidative studies were carried out to evaluate the oxidative stability of soybean oil triacylglycerols obtained from genetically modified soybeans. Oxidative stability was improved due to the modification of the fatty acid composition in which polyunsaturated acids (such as linolenic and linoleic acids) were decreased and in which monounsaturated fatty acids (such as oleic) and saturated acids (palmitic and stearic) were increased (Neff, 1999). Another study has been carried out to determine possible associations between seed size and fatty acid composition in diverse genotypes: there were significant correlations between seed size and individual fatty acids: positive with stearic and oleic, and negative with linoleic (Maestri, 1998).
WALNUT OIL: It is the expeller pressed oil from the ripe fruit of the tree Juglans regia, which is commonly known as the white or English walnut. It is characterized as a pale yellow, clear oil having a large percentage of linoleic acid. Due to its high content in unsaturated fatty acids, shows low stability properties, limiting its use in cosmeticals.

WHEAT GERM OIL: It is the extracted oil from the germinated seeds of Triticum sativum. This oil contains phospholipids and an unsaponifiable with a high content in carotenoids and tocopherol. It is frequently used as nutritious active ingredient for the care of the delicate and sensitive skins (Pons, 1995).

Another oils are: Tomato seed oil, that was found to contain high levels of linoleic (Lazos, 1998), pumpkin oil, which fatty acid composition showed that the predominant were linoleic $(42 \%)$ and oleic (38\%) (Tsaknis, 1997), peanut oil, cottonseed oil, etc.

Finally, as a summary, some cosmetic applications of vegetable oils are collected in table III.

\section{Fish oils}

Fish marine oils are produced from the body or the liver of the fish. Fish lipids provide an ideal and natural source of the essential fatty acids, EPA, DHA and DPA (Nieto, 1997). The consumption of fish lipids provides the body with a direct source of the $\omega-3$ series of fatty acids bypassing the need to convert alpha-linolenic acid to EPA and DHA.

Numerous studies have shown that $\omega-3$ fatty acids help lower cholesterol and blood triglycerides, and help prevent clots in arteries which may result in strokes, heart attacks and thromboses. EPA is used as pharmaceuticals, due to its effectiveness at reducing cholesterol and neutral lipids in the bloodstream and improving circulation At the same time, DHA is garnering attention as a fatty acid essential to the brain and other neural tissue. The fatty acid composition of the fish oils may be different according to species and season.

Table III

\section{Cosmetic uses of vegetable oils}

\begin{tabular}{|l|l|l|}
\hline \multirow{4}{*}{ Facial care } & Normal skin & Almond, apricot, hazelnut, borage, jojoba \\
\cline { 2 - 3 } & Dry to normal skin & Almond, apricot, avocado, olive, wheat germ, borage, jojoba, macadamia \\
\cline { 2 - 3 } & Oily to normal skin & Almond, apricot, grapeseed, hazelnut, borage \\
\hline \multirow{3}{*}{ Hair care } & Normal hair & Almond, borage \\
\cline { 2 - 3 } & Dry hair & Almond, avocado, borage, cocoa butter, jojoba, sesame, macadamia \\
\cline { 2 - 3 } & Oily hair & Borage, sesame \\
\hline
\end{tabular}


In a recent study (Gámez-Meza, 1999), the fatty acid profiles of sardine oils from Sardinops sagax caeruleus of the Gulf of California, were evaluated in three seasonal catch periods. The most abundant fatty acids found in the oils were palmitic acid (19.3\%), oleic acid (14.3\%), EPA (20.4\%) and DHA (12.2\%). There was no significant difference in the composition and quality among the six reduction plants where the samples were obtained. However, a significant difference in the proportion of EPA and DHA in one of the catch seasons analyzed was observed.

In another study, fatty acid composition of the liver oil from the Black Sea dogfish (Squalus acanthias) seasonal variations were also determined (Stefanov, 1997).

\section{Bird oils}

Currently three major species of birds from the Ratite family are being raised in the United States, namely the emu, ostrich, and rhea. These birds are produced primarily for their meat, oil, and leather. The oils obtained from all three species of ratites appear to be similar in their basic composition. These oils are triglycerides composed mostly of oleic, palmitic, stearic, and linoleic fatty acids. The proportions of these fatty acids will vary somewhat according to the type of bird and possibly the type of feed. Even though the relationship between animal feed and and oil compositions has not been studied in depth, it is likely that the degree of saturation of the fatty acids in the oil will be affected to a certain extent by the type of fats in the animal feed (Zemtsov, 1996).

The main market for these oils is the cosmetics industry. Examples of some commercial products made with ratite oils include moisturizing creams, body lotions, soap, lip balm and sports ointments.

EMU OIL: Most of the published data on ratite oils is on the emu. Emu are members of the Ratite family of flightless birds, which have small or underdeveloped wings. Emu, the world's second largest living bird have survived 80 million years in their native Australia where they are found in the deserts, forests and on the plains. In 1960, the emu was designated Australia's national bird. The main cosmetic and pharmaceutical properties attributed to this oil are skin penetrating, moisturizing, antiarthritic and anti-inflammatory (Zemtsov, 1996). Work done by Ghosh et al., (1996) reported that emu oil, in combination with ethyl salicylate, isopropyl salicylate, and oil of eucalyptus, has antiinflammatory and anti-arthritic activity when tested in laboratory rats with induced polyarthritis. Emu oil is also reported by these workers to suppress human granulocyte elastase, a tissue degenerative enzyme that is released when tissue inflammation occurs. Zemtsov et al. reported a double-blind study on the moisturizing and cosmetic properties of emu oil, noting that emu oil had skin permeability and moisturizing properties superior to mineral oil. It has been also reported that emu oil increased the proliferation of cells and the growth of hair follicles in lab rats. Some of the cosmetic properties of the oil appear to increase synergistically when used in combination with phospholipids from other oils used in cosmetics such as palm, sesame, safflower, borage and coconut.

\subsubsection{Fats}

Fats are solid at room temperature. They are usually derived from animals and are complex mixtures. Fats have a higher percentage saturated fatty acids than do oils.

\section{Vegetable fats}

The fruit and the seeds of diverse vegetable species contain fatty fractions of consistency between solid and pasty that are known with the name of vegetable fats. They are mixtures of heterogeneous composition, although they almost always present a high content in saturated triglycerides. Next, the better known vegetable fats are indicated.

COCOA OIL: Oil of Theobroma or cacao butter is a yellowish white solid, with an odour resembling that of cocoa, taste bland and agreeable, generally extracted by expression from the seed of Theobroma cacao. It has excellent emollient properties and is used to soften and protect chapped hands and lips. Applied externally, cocoa butter has emollient virtues. It also presents greasing and lubricating properties. It is allotted skin conditioning and thickening virtues. Cocoa butter is thus a good active ingredient for feel and firmness in lip balms, softening hand creams, moisturizing soaps, emollient creams for combination, normal or dry, sensitive and delicate skin. It is used as an excipient in ointments and for coating tablets and preparing suppositories (del Arco, 1997). It has diuretic effect due to stimulation of the renal epithelium; it is especially useful when there is an accumulation of fluid in the body resulting from cardiac failure, when it is often given with digitalis to relieve dilatation.

Coconut OIL: It is the oil from Cocos nucifera. Due to its high content in saturated fatty acids (lauric, 50\% and myristic, 20\%) is an excellent fat for the synthesis of most of the cosmetic detergents. It is also used in sunscreens (Dave, 1987). It also contains caprilic and caprinic acids (Pons, 1995).

PALM OIL: It is the expressed oil from the fruit of Elaeis guineensis. This oil is also known as vegetable tallow. Because of its high content in unsaturated fatty acids (oleic, 50\%; linoleic, 5-10\%), may become rancid. They are also present unsaturated fatty acids 
(palmitic, $>30 \%$ and small amounts of stearic and myristic acids). Unsaponifiable is very scarce, but it contains a relatively high proportion of carotenoids. It is used for the production of soaps and, occasionally, in products cosmetic dealers. Palm oil adds firmness to bar soaps and is used in many luxury soaps (Pons, 1995).

SHEA BUTTER: It is also known as african karite butter. It is obtained from the seeds of Butyrospermum parkii that grows in a wide area in Central Africa. Shea butter has the aspect of a soft paste or melted fat, with a greenish, yellowish or whitish colour and a more or less characteristic pleasant odour. Crude shea butter has natural antioxidant properties due to its content in tocopherols. The content in shea butter of unsaponifiable fats is remarkable in comparison with other oils. This unsaponifiable helps keep the skin young by stimulating the tissue and helping the skin make its own collagen. The product is therefore much appreciated in the cosmetic industry. Shea butter has soothing, moisturizing and protecting effects. Due to the presence of a sizeable quantity of unsaponifiable fats, its content in vitamins and other active elements, shea butter adds other more precise activities to these general properties: it has restructuring effects on the epidermis, also on dry and fragile hair; it has an antielastase characteristic which makes it a good active ingredient against stretch marks. Shea butter has also an activity on cell regeneration and capillary circulation. This favours the healing of small wounds, skin cracks and crevices, and skin ulcers. In the cosmetic field, this property is an asset against skin ageing. It displays a protecting role against UV rays because of its content in cinnamic acid and can thus be incorporated in solar products. The latex contained in shea butter would moreover prevent certain sun allergies (Tella, 1979). It is therefore an outstanding product for cosmetic and pharmaceutical purposes, even incorporated in high proportions. It is easy to work into all kinds of emulsions and makes a very good excipient as it prevents allergenic reactions without altering the active principles. When added to soaps it gives an exotic feel. It can also be added to creams and lotions or used alone for massage or skin cream.

The free fatty acid profiles of some vegetable oils and fats are depicted in table IV (Madrid, 1997).

\subsubsection{Waxes}

Waxes are esters formed by the combination of fatty acids with high molecular weight monohydroxy alcohols. Waxes minimize water loss on plants and act as waterproofing on animals. In most cases, waxes are hard, brittle substances with high melting points. Liquid wax esters like those from jojoba seed and sperm whale oil are used in diverse commercial products as lubricants, cosmetics, solid wax coatings and biofuel additives. Similar wax esters can also be produced by microorganisms (del Arco, 1997).

JOJOBA OIL: It is a mixture of long chain, linear liquid wax esters extracted from the seeds of the desert shrub Simmondsia chinensis. Jojoba's liquid esters provide superior oxidative stability, excellent emolliency and effective moisturization to the hair and skin (Wisniak, 1977). Human sebum and jojoba oil are virtually identical. Sebum protects and moisturizes the skin and hair, but it is stripped away by chemicals, pollutants, the sun, and the aging process, resulting in dry skin and hair. Jojoba oil replenishes what skin and hair lose, and it restores them to their natural $\mathrm{pH}$ balance. This oil beautifies and protects normal skin and hair. Jojoba reduces wrinkles, treates psoriasis, acne, and neurodermatitis, and brings the skin back to its normal vitality and healthy glow. Jojoba oil is similar to, and has replaced, sperm whale oil. However, contact dermatitis from jojoba oil has been reported (Wantke, 1996). Used as an additive, jojoba oil improved the viscosity index of lubricants. When subjected to heating and cooling from 40 to $200^{\circ} \mathrm{C}$, the chemical structure, kinematic viscosity and refractive index remained almost constant. Thus, jojoba oil was highly stable in this temperature range.

BEES WAX: It is secreted by the glands of Apis mellifera, acquiring consistency when it mixes with the saliva of the bee. This wax has the same sweet smell as honey and will impart excellent properties to body-care products. It is added to bar soaps to make them harder. It is also used in creams, lotions and lip balms (Millet, 1992; del Arco, 1997). Bee wax is used as an excipient in formulations with the purpose of increasing viscosity and consistency of the preparations.

SPERMACETI: It is a waxy substance obtained from the head of the sperm whale (Physeter macrocephalus). It is mainly constituted by cetyl palmitate, cetylic alcohol and other esters that contain fatty alcohols and fatty acids. Spermaceti is white, somewhat translucent, slightly unctuous, free of rancidity. It is one of the solid fatty substances formerly employed to give consistency and texture to cerates and ointments. For diverse reasons, this regulator of the consistency of many emulsions is being displaced by synthetic esters of similar characteristics (del Arco, 1997).

LANOLIN: Lanolin is a complex mixture of esters of fatty acids and high molecular weight alcohols, including aliphatic or steroid alcohol. Up to $12 \%$ consists of free fatty alcohols. It is obtained by refining the unctuous sebaceous secretion (wool fat) of sheep. Lipid components from lanolin can be extracted to use them separately in many formulations. Lanolin alcohol is extracted by hydrolysis of lanolin. It has strong water in oil emulsifying properties, absorbing up to 2000 times 
Table IV

Composition (\%) of principal oils and fats used in cosmetic and pharmaceutical sciences

\begin{tabular}{|c|c|c|c|c|c|c|c|c|c|c|c|}
\hline \multirow[b]{2}{*}{ Oil } & \multicolumn{4}{|c|}{ S.F.A. } & \multicolumn{6}{|c|}{ P.U.F.A. } & \multirow{2}{*}{$\begin{array}{c}\text { Other } \\
\text { components }\end{array}$} \\
\hline & $\begin{array}{l}\text { Lauric } \\
(12: 0)\end{array}$ & $\begin{array}{c}\text { Myristic } \\
(14: 0)\end{array}$ & $\begin{array}{c}\text { Palmitic } \\
(16: 0)\end{array}$ & $\begin{array}{c}\text { Stearic } \\
(18: 0)\end{array}$ & $\begin{array}{c}\text { Palmitoleic } \\
(16: 1)\end{array}$ & $\begin{array}{l}\text { Oleic } \\
(18: 1)\end{array}$ & $\begin{array}{c}\text { Linoleic } \\
(18: 2)\end{array}$ & \begin{tabular}{|c} 
Linolenic \\
$(\mathrm{C} 18: 3)$
\end{tabular} & DHA & EPA & \\
\hline Almond & & & $4-9$ & $2.5 \max$ & 0.6 & $60-86$ & $7-30$ & $0.1-1.0$ & & & \\
\hline Apricot & & & $3-6$ & $2 \max$ & 1.4 & $55-70$ & $25-35$ & $1 \max$ & & & \\
\hline Avocado & & & $12-20$ & $0.1-2.0$ & $2-10$ & $55-75$ & $9-17$ & $0.1-2.0$ & & & \\
\hline Borage & & & $9-12$ & $3-4$ & & $15-20$ & $30-40$ & $18-25$ & & & \\
\hline Canola & & & $2-7$ & $1-3$ & & $50-65$ & $15-30$ & $6-14$ & & & \\
\hline \multicolumn{12}{|l|}{ Castor } \\
\hline Coffee & & & $30-45$ & $5-9$ & & $8-10$ & $40-50$ & $0.1-3$ & & & \\
\hline \multicolumn{12}{|l|}{ Corn } \\
\hline Cottonseed & & & $17-29$ & $1-3$ & & $16-44$ & $33-58$ & $<2$ & & & \\
\hline Grapeseed & & & $5-10$ & $3-5$ & & $12-26$ & $58-77$ & & & & \\
\hline Macadamia & & & $7-11$ & $4 \max$ & $18-22$ & $55-63$ & $5 \max$ & $1 \max$ & & & $\begin{array}{c}\text { Arachidic (4) } \\
\text { Eicosenoic (4) }\end{array}$ \\
\hline Pumpkin & & & 12.7 & 6 & & 38 & 42 & & & & \\
\hline Safflower oleic & & & $4-9$ & 2.5 & & $72-80$ & $12-16$ & $0.5 \max$ & & & \\
\hline Safflower linoleic & & & $4-9$ & 2.5 & & $75-80$ & $12-16$ & $0.5 \max$ & & & \\
\hline Soybean & & & $7-12$ & $2-6$ & & $20-35$ & $45-60$ & $5-10$ & & & \\
\hline Sunflower & & & $3.5-8$ & $3-7$ & & $15-85$ & $50-72$ & $<0.2$ & & & \\
\hline Sesame & & & $7-12$ & $3.5-6$ & 0.5 & $35-50$ & $35-50$ & $1 \max$ & & & \\
\hline Tomato & & & 14 & 6 & & 22 & 54 & & & & $\begin{array}{l}\beta \text {-sitosterol } \\
\text { cholesterol }\end{array}$ \\
\hline Walnut & & & $6-9$ & $2-3$ & & $15-20$ & 57 & 62 & $11-14$ & & \\
\hline Wheatgerm & & & $9-17$ & $1-3$ & & $22-40$ & $45-65$ & 1 & & & \\
\hline Cocoa & & & $25-30$ & $31-35$ & & $34-36$ & 3 & & & & \\
\hline Coconut & 50 & 20 & 16 & 3 & & 4 & & & & & \\
\hline Palm & & & 30 & & & 50 & $5-10$ & & & & \\
\hline Peanut & & & $8-13$ & $3-5$ & & $38-63$ & $18-42$ & & & & \\
\hline Shea butter & & & 6 & 38 & & 49 & 4 & & & & \\
\hline
\end{tabular}

its own weight, and is used as a binder, emulsion stabilizer, skin conditioner, hair conditioner and viscosity-increasing agent in products such as lipsticks, make-up, eye products and creams and lotions. Liquid lanolin is obtained by solvent fractionation of lanolin. It is odorless, tasteless and soluble in mineral oil, making it useful in bath oil products. The other component of fractionation is lanolin wax. This substance is also odorless and tasteless, and is a better water in oil emulsifier than plain lanolin. It is used primarily in lispsticks and glosses. Hydrogenated lanolin is a more saturated 
derivative with a large percentage of free alcohols. It has increased water absorption and mineral oil solubility, is odorless and tasteless, and is used in lip products, scented moisturizing ad night creams and lotions, cleansing products and emulsion formulas. Acetylated lanolin is a more hydrophobic product with a high ester and low alcohol content. It is useful in water-resistant products such as sunscreens, baby products, and hand and body creams (del Arco, 1997). Ethoxylated lanolins, also known as polyoxyethylene lanolins, are reacted with ethylene oxide, resulting in a more hydrophilic product containing 6 to $75 \mathrm{~mol}$ of ethylene oxide. They are used as solubilizers in sunscreens, perfumes, pharmaceuticals, hair products, shampoos, soaps, dishwashing detergents, aftershave lotions, preshave lotions, astringent lotions and colognes. Transesterified lanolin is partially saponified and is more soluble and spreadable than lanolin. It is used to create a lighter velvety-feeling emulsion in nongreasy formulations (Smolinske, 1992). On the other hand, several puzzling aspects of the use of lanolin are discussed by Wolf (1996). In this paper, it has been reported that lanolin in topical therapeutic agents sensitizes a high proportion of patients, whereas the same lanolin is 'safe' in cosmetics so widely used by millions of individuals.

\subsection{Fatty acids}

The combination of fatty acids with glycerol to form glycerides is sometimes reversed resulting in the presence of uncombined or free fatty acids. These are usually found in crude oils and may be removed by neutralisation.

Fatty acids are long molecules consisting of a hydrocarbon chain with a carboxylic acid group at the end. The long tail of the molecule, made up of carbon and hydrogen, is not attracted to water. The carboxylic acid «head" can form hydrogen bonds with water, and is therefore strongly attracted to water. When a fatty acid is placed on a water surface, the hydrophilic heads of the molecules are attracted to the water. As a result, the molecules form a monolayer on the surface of the water with their heads sticking into the water and their hydrophobic tails sticking up above the surface of the water.

Although fatty acids are relatively large molecules, they are not biopolymers made up of consecutive units like carbohydrates and proteins.

Fatty acids, as a group, are a member of the larger class of ubiquitous lipids, which carry out numerous biochemical functions ranging from construction of cellular membranes to providing food under starvation conditions.

Recently, fatty acids have come under heavy scrutiny for their role in heart disease and arteriosclerosis and many people are trying to reduce the amount of fatty acids in their diet (Fan, 1998; Truswell, 1998).

Fatty acids derivates (fatty acid soaps, simple fatty acid ester, modified fatty acid ester and fatty alcohol ether) are used as emulsifiers in many foods, cosmetical and pharmaceutical preparations (del Arco, 1997).

If the free bonds in a fatty acid chain of carbon atoms are not all occupied by hydrogen atoms, the fatty acid is said to be unsaturated. Oils consisting mainly of the glycerides of unsaturated fatty acids are generally liquid at normal temperatures. They may be made more solid by hydrogenation which reduces the degree of unsaturation. Fatty acids containing only one unsaturated bond are called «monounsaturated»; those with more than one unsaturated bond are called «polyunsaturated».

OLEIC ACID (18:1): It is employed in cosmetical and pharmaceutical formulations as an excipient. It is used in topical and parenteral pharmaceutical formulations. It has also been used as penetration enhancer in transdermal formulations (Morgan, 1998), to improve the bioavailability of poorly-water soluble drugs in tablet formulations, and as raw material for ointments, creams, etc.

LINOLEIC (18:2) AND LINOLENIC (18:3) ACIDS are used in cosmetic products. They influence on metabolic processes in the skin, promote the activity of vitamins $A$ and $E$ and recovery barrier properties of stratum corneum (Belotserkovets, 1998; Huang, 1999).

\subsection{Compound lipids}

\subsubsection{Phospholipids}

Phospholipids are amphipatic molecules. The head of a lipid molecule is negatively charged phosphate group and the two tails are highly hydrophobic hydrocarbon chains. Phospholipid tails will congregate together to form a local hydrophobic environment. This leaves the charged phosphate groups facing out into the hydrophilic environment. There are three structures that phospholipids can form because of their amphipatic nature: micelles $(A)$, planar lipid bilayers (B) and vesicles (C) (Figure 1).

A phospholipid bilayer is approximately $5 \mathrm{~nm}$ thick. This membrane is semipermeable, meaning that most molecules are excluded but some molecules are allowed to pass freely through the membrane.

A broad range of phospholipids are suitable for use in cosmetics, pharmaceuticals and diagnostics. Phospholipids are used as a vehicle for therapeutic substances. They are also used for preparing liposomes. Liposomes are small vesicles formed by a membrane bilayer of phospholipids which contain 


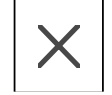

A



B

Figure 1

Structures that lipids can form

different substances of pharmaceutical or cosmetic interest (Ostro, 1989).

Liposomal encapsulation or incorporation in a lipid complex can substantially affect a drug's functional properties relative to those of the unencapsulated or nonlipid-associated drug. In addition, different liposomal or lipid-complexed products with a common active ingredient may vary from one another in the chemical composition and physical form of the lipid component. Such differences may affect functional properties of these drug products (Ostro, 1992).

Lipid-complexes products are a therapeutic option to decrease toxicity of some drugs, such as Amphotericin B (Janoff, 1993).

Conventional amphotericin B has been generally considered the drug of choice for many types of systemic fungal infections. These infections are a major threat to those whose immune systems are compromised, such as patients undergoing chemotherapy for cancer, bone marrow transplant recipients and AIDS patients. However, amphotericin $B$ is very toxic, thus limiting its utility. For these patients, who have a high rate of morbidity and mortality, there is a dosage form distinct from conventional amphotericin $B$, which consists of amphotericin B complexed with two phospholipids in approximately a 1:1 drug-to-lipid molar ratio: L-a-dimyristoylphosphatidylcholine (DMPC) and L-a-dimyristoylphosphatidylglycerol (DMPG), present in a 7:3 molar ratio (Fromtling, 1996; Hiemenz, 1996; Baddour, 1997). Clinical experience demonstrates that the complexing of amphotericin B with these phospholipids reduces commonly observed toxicities of amphotericin B, particularly those affecting the kidney (Dix, 1996).

Liposomal doxorubicin is designed to target to tumor cells and spare healthy tissue, maintaining efficacy while reducing toxicity. Conventional doxorubicin, drug commonly used to treat cancer, is limited by its potential for causing a variety of severe side effects, particularly irreversible heart damage (Batist, 1998). Programmed Fusogenic Liposomes (PFV) are designed to deliver bioactive compounds to the cytoplasm of cells by fusing with cell membranes in a controlled, regulated manner. PFV contain a pegylated-ceramide which acts to stabilize components such as N-(1-(2,3dioleoyloxy)propyl)-N,N, N-trimethylammonium chloride (DOTAP) and DOPE in the membrane bilayer. DOTAP, a cationic lipid, is incorporated into these formulations to promote "passive» binding of liposomes to target cells (which bear a net negative charge), whereas DOPE is included as a «fusogenic» lipid. The presence of the pegylated ceramide has been shown to inhibit fusion between liposomes as well as between liposomes and cells.

Synthetic phospholipids are suitable for specific applications in liposome targeting and gene therapy (Hodgson, 1996; Li, 1998).

Gene therapy delivery is attempting a solution for the efficient delivery of genes to their intended targets. Researchers have successfully put DNA into liposomes and have achieved fusion of these liposomes to cells, thereby accomplishing the direct delivery of the liposome contents into the cell interior. Scientists have also succeeded in protecting these liposomes from degradation and are able to modulate their circulation time. Researchers are now developing systems to target these fusogenic liposomes to particular cell types (Balasubramaniam, 1996; Zuidan, 1999).

It is also possible to find in the bibliography liposomes made with different types of phospholipids: distearoylphosphatidylcholine (Ahl, 1997), dipalmitoylphosphatidylcholine (Jones, 1997; Asai, 1999), etc.

\subsubsection{Lecithin}

Lecithin is a lipid complex compound of glycerol containing phosphorus. It has two fatty acid radicals and a third radical which is a complex organic base containing both phosphorus and nitrogen. It has strong emulsifying properties and is also used in food industry, pharmaceuticals and cosmetics (Smolinske, 1992; Helme, 1992).

Lecithins are an important structural component of the cell membrane, where it maintains continuity between the water and lipids phases inside and outside the cell.

It is commonly used as an emulsifying agent and skin conditioner. Types of products include shampoos, make-up foundations, blushes, lipsticks, and moisturizing creams or lotions. The usage of lecithin considerably increases quality of cosmetic products (nutritius, rejuvenation, regenerating functions), and considerably improves its organoleptic parameters without significant rise in price (Kusmina, 1998).

\subsubsection{Sphingolipids}

Sphingolipids are compound lipids that contain a sphingoid group. 


\subsubsection{Ceramides}

Ceramides are sphingolipids that contain an $\mathrm{N}$-acetylated sphingoid. They are skincare cosmetic ingredients for regulating transepidermal water loss and promoting epidermal barrier repair.

The main barrier function of a skin belongs to the multilamellar lipid sheets of the stratum corneum. These lipids are formed in the deeper layers of epidermis, and then lose their polar heads under the action lipolytic enzymes on its way to a surface. Thus, lamellar structures cementing cells of epidermis are formed from fatty acids, acylglycerols and ceramides.

In a growing old skin, under influence of external environment, including agents for clearing skin, lipids leave the stratum corneum, making epidermis more permeable. It results in deterioration of barrier function of skin and increasing of water loss. Therefore, application of "substituting therapy» by inclusion in cosmetic agents ceramides and other normal components of a lipid barrier is a simple and effective way of reconstruction of skin barrier function. Ceramides are combined with epidermis growth stimulators such as alfa-hydroxiacids and retinoids (Moureaux, 1995).

Hair also loses lipids. With increasing age, the perceptible characteristics of the hair are altered. In healthy hair, the edges of the cuticle cells are smooth and the patterns of the cuticle are regular. In damaged hair, the cuticle edge is missing and in some parts, the scale lifting and loss progresses to underlying layers. When the damage has progressed further, the cuticle is almost completely missing and the cortex is exposed. The result of the accumulated damage is limp, dull, split and broken hair. This weakened hair, now with a dramatically lowered tensile strength, is then chronically exposed to chemicals, harsh surfactants, U.V. radiation and mechanical and physical constraints imposed on the hair. Ceramides applied on this biologically dead structure, exhibit new ways in which subtle modifications may provide care and protection of the hair fiber (Kaplun, 1998).

\subsubsection{Sphingosines}

Phytosphingosine and tetraacetylphytosphingosine are used for rejuvenation of skin. It have antimicrobial and antiinflamatory effects.

\subsection{Derived lipids}

\subsubsection{Steroids}

The steroids are chiefly hormones, including estrogen and testosterone. Cholesterol is an steroid that is component of the cell membrane, and an important factor in the disease atherosclerosis (Kruth, 1997; Bocan, 1998). Cholesterol is used as an ingredient in some pharmaceutical preparations as liposomes.

Sterols are also required for the growth of most fungi. It has been established that the more primitive taxa of fungi have cholesterol and related sterols while the more advanced taxa have ergosterol as the major sterol (Parks, 1998).

\section{LIPIDS AS ACTIVE SUBSTANCES IN PHARMACEUTICALS}

Up to now, the most important lipids used in the pharmaceutical and cosmetic Industry as exicipients in medicines and cosmetics has been described. Next, it will be carried out a study of lipids, in function of their biological activity, as active substances for the elaboration of pharmaceuticals, cosmetics or nutritional supplements.

\subsection{Triglycerides}

Triglycerides are the chemical form in which lipids exist in food as well as in the body. In plasma they are derived from fats eaten in foods or made in the body from other energy sources like carbohydrates. Calories ingested in a meal and not used immediately by tissues are converted to triglycerides and transported to fat cells to be stored. Hormones regulate the release of triglycerides from fat tissue so they meet the body's needs for energy between meals.

\subsubsection{Vegetable oils}

BORAGE OIL: Contains 20-24\% gamma-linolenic acid (GLA), a non-essential fatty acid, which has been shown to have many beneficial effects. It has the highest GLA content of any plant source. Studies show borage oil to be beneficial in the treatment of rheumatoid arthritis, atopic eczema and diabetic neuropathy, as well as in the reduction of cholesterol levels (Barre, 1992; Mancuso, 1997; Henz, 1999).

CANOLA OIL: It is the oil from canola, a genetic variation of rapeseed developed by Canadian plant breeders specifically for its nutritional qualities, particularly its low level of saturated fat. The fatty acid composition of canola oil is consistent with its use as a substitute for SFA, in meeting the dietary goals recommended by many health associations. Canola oil is a newly marketed edible vegetable oil for use in salads and for cooking that contains 55\% of oleic acid, $25 \%$ linoleic acid and $10 \%$ alpha-linolenate and only $4 \%$ of the saturated fatty acids that have been implicated as factors in hypercholesterolemia (Dupont, 1989). Health 
practitioners and dieticians have praised the fatty acid profile of canola, labelling it the oil with the best fatty acid ratio. Research indicates the fatty acid composition of canola oil is most favourable in terms of health benefits and as part of a nutritionally balanced diet.

EVENING PRIMROSE OIL: Is extracted from the seeds of Oenothera biennis (Onagraceae), a plant native to North America and which is now widely cultivated in temperate countries. This oil has a high content of glycerides of linoleic acid $(65-80 \%)$ and gamma-linolenic acid (7-14\%). Because of this high gamma-linolenic acid content, evening primrose oil is widely used as a dietary supplement, providing additional quantities of this essential fatty acid (Dewick, 1997). It has been suggested that the alpha-linolenic acid contained in perilla oil is less atherogenic than oleic and linoleic acid, and gamma-linolenic acid contained in evening [corrected] primrose oil has a tendency to decrease the plasma lipid level. (Sadi, 1996).

OLIVE OIL: Significantly increased the plasma HDL cholesterol concentration, but only decreased the plasma LDL cholesterol concentration in healthy subjects (Ruiz-Gutiérrez, 1998). Moreover, olive oil was able to significantly diminish the systolic and diastolic blood pressures in hypertensive patients (Muriana, 1998). Olive oil enriched-diet may modulate and/or partially prevent the alteration of those pathogenic parameters related to human hypertension and cardiovascular pathology, although these processes cannot be exclusively ascribed to the content of oleic acid in virgin olive oil. The fraction of sterols and triterpenic dialcohols from the unsaponifiable of virgin olive oil has been tested for its possible anti-inflammatory activity. The topical administration of these products a potent anti-edematous effect, in the auricular edema induced by TPA (12-O-tetradecanoylphorbol acetate) in experimental animals (de la Puerta, 1997). In other study, it has been reported that virgin olive oil succesfully protects mitochondrial membranes from aged rats against the free radical insult (Huertas, 1999).

\subsubsection{Fish oils}

The relationship between fish oils and atherosclerosis appears to be an intimate one. The higher the consumption of fish, the lower the risk of dying from coronary heart disease. In people with coronary heart disease, fish oils may reduce the risk of thrombosis, reduce the pain of angina and improve cardiac function. There is even preliminary evidence that they may inhibit the development of atherosclerosis.

According to studies published in Lancet (Anonymous, 1986), the incidence of heart disease related to atherosclerosis, including coronary artery disease, in Greenlandic Eskimos is extremely low. From 1963 to 1967 only three cases of these diseases were reported in the entire Eskimo population of Greenland.

Since diabetes and heart disease affected literally millions of Americans in the 1980's and 1990's, the lack of heart disease in Eskimos and other societies has attracted the serious attention of many scientists around the world. Low mortality from coronary heart disease among Eskimos has been attributed to less atherosclerosis in the coronary arteries because of a high dietary intake of omega-3 fatty acids (Newman, 1993).

The food of the Greenlandic Eskimos consists largely of meat from whales, seals, sea birds and fish (usually halibut and salmon). Needless to say, their food is extremely rich in protein and fat and low in carbohydrates, but it is extremely high in the omega-3 polyunsaturates EPA and DHA (Harris, 1999).

In many studies there is evidence that high levels of EPA and DHA found in the fish, seal and whale diet of the Eskimo may be protective against heart disease (Ponte, 1997).

SHARK LIVER OIL is obtained from the liver taken from deep sea sharks. Scandinavian fishermen have been using shark liver oil since the 16th century. It is used to combat viral infections such as colds and influenza as an antiseptic to heal wounds. It has composed of $60 \%$ unsaponifiable matter, containing $45 \%$ squalene, $5 \%$ cholesterol and $10 \%$ of linear saturated and monounsaturated glycerol ethers with 14 - 18 carbon atoms (Bordier, 1996). The active ingredients in shark liver oil have found to be a group of ether-linked glycerols known as alkylglycerols. They are special marine lipids that support the production of white blood cells, particularly the T-Lymphocytes which are critical to the proper function of the immune system. The immune supportive nutritional effect of alkoxyglycerols helps the body protect against all three types of common offenders including bacterial, fungal and viral infections. These natural immune supporting nutrients also help the immune system fulfill its role of warding off the progression of other degenerative conditions: AIDS, cancer, auto-immune disorders and allergic reactions (Pugliese, 1998).

\subsubsection{Fats}

SHEA BUTTER can be used to treat rheumatism and aching muscles, and to ease colds because it decongests nasal mucous tissues (Tella, 1979).

\subsection{Fatty acids}

Fatty acids have an important role to prevent cardiovascular diseases. SFA are the main dietary culprit in raising blood cholesterol. Diets high in SFA 
and trans fatty acids increase LDL cholesterol levels, and in turn, the risk of heart disease. (Lichtenstein, 1998). The main sources of SFA in the diet are foods from animals (beef, veal, lamb, pork, butter, cream, milk and cheeses) and some plants (coconut oil, palm oil and cocoa butter).

UFA tend to help the body get rid of newly formed cholesterol. Thus, they keep the blood cholesterol level down and reduce cholesterol deposits in artery walls (Poschl, 1999). Monounsaturated oils are liquid at room temperature but start to solidify at refrigerator temperatures. Olive and peanut oils and avocados are sources of monounsaturated fatty acids. Polyunsaturated oils are liquid. They easily combine with oxygen in the air to become rancid. Common sources of polyunsaturated fatty acids are safflower, sesame and sunflower seeds, corn and soybeans, many nuts and seeds, and their oils.

\subsubsection{Saturated fatty acids}

CAPRYLIC ACID is an antifungal, short chain, fatty acid having the chemical name octanoic acid. Caprylic acid is a fatty acid derived from coconut oil and has been found to exhibit antifungal properties. It specifically is effective for gastrointestinal Candida overgrowth. Once absorbed, caprylic acid is no longer antifungal but is then metabolized to produce energy.

The antifungal effect of caprylic acid has been demonstrated in both clinical and in vitro studies. In the $\mathrm{pH}$ range of 2.5-8.5, caprylic acid exhibits high fungicidal activity against yeasts, especially Candida albicans. The exact mechanism of fungicidal action is not fully understood; however, it is postulated that caprylic acid dissolves in the cell membrane of yeast causing changes in fluidity and permeability that lead to membrane disaggregation.

Caprylic acid is readily absorbed in the intestines; however, sustained release dosage forms allow for a slow, uniform dispersion along the intestinal length ensuring delivery of caprylic acid to the colonic region where Candida infestation is usually maximal. It has been said that Candida migrate into the mucosal wall. Because of its lipotrophic properties (which allow it to penetrate mucosal cells) caprylic acid is also believed to be effective against intramucosal Candida. Absorbed caprylic acid can be oxidized both in the mitochondrial and extra-mitochondrial compartments of mammalian tissues thereby eliminating additional toxic burden to the liver.

\subsubsection{Monounsaturated fatty acids}

OLEIC ACID has been shown to reduce serum levels of total cholesterol and LDL cholesterol levels. Oleic acid does not affect levels of HDL cholesterol.
To reduce serum levels of total cholesterol and low-density lipoprotein cholesterol, without reducing caloric intake, it may be beneficial to substitute the whole milk customarily consumed by children with a milk preparation of fat-free milk enriched with oleic acid (Estévez-González, 1998).

\subsubsection{Polyunsaturated fatty acids}

Numerous studies have shown that these fatty acids help lower cholesterol and blood triglycerides, and help prevent clots in arteries which may result in strokes, heart attacks and thromboses (Ponte, 1997).

LINOLEIC and $\alpha$-LINOLEIC are referred to as essential fatty acids since they and their metabolites are required for normal good health. Some food sources such as the oils present in fish are rich in the later metabolites derived from $\alpha$-linolenic acid (EPA and DHA), and are also beneficial to health. Since these fatty acids all have a double bond three carbons from the methyl end of the chain, they are grouped together under the term $\omega-3$ fatty acids.

Although most plant-derived oils contain high amounts of unsaturated fatty acid glycerides, including those of linoleic and $\alpha$-linoleic acids, the conversion of linoleic into $\gamma$-linolenic can be blocked or inhibited in certain conditions in humans. This restricts synthesis of prostaglandins. In such cases, the use of food supplements (evening primrose), which are rich in $\gamma$-linolenic esters, can be valuable and help in the disorder.

ARACHIDONIC ACID itself has not been found in higher plants, but does occur in some algae, mosses and ferns. Arachidonic acid is a precursor of the prostaglandins, thromboxanes and leukotrienes, which show a range of pharmaceutical activities and also stimulates protein kinase redistribution in heart cells (Kim, 1992; Blobe, 1995; Huang, 1997).

Lipoxins are arachidonic acid-derivatives products. They were first isolated in 1984 and play critical roles in inflammation and other multicellular vascular processes, including atherosclerosis and thrombosis (Serhan, 1997).

Animals need linoleic for the biosynthesis of dihomo- $\gamma$-linolenic and arachidonic, polyunsaturated fatty acid precursors of prostaglandins in the «one» and «two» series respectively. Linoleic acid must be obtained from plant material in the diet, and then desaturated near the carboxyl end to yield $\gamma$-linolenic, which is then used as the substrate for further chain extension, producing dihomo- $\gamma$ linolenic. Arachidonic derives from this additional desaturation, again towards the carboxyl end of the chain. $\alpha$-linolenic is similarly a precursor on the way to EPA, required for the synthesis of prostaglandins of the three series, and it is also obtained from the diet (Dewick, 1997). 
Polyunsaturated fatty acids (linoleic acid, linolenic acid, arachidonic acid and DHA) but neither the monounsaturated oleic acid nor the saturated stearic acid), reduce membrane electrical excitability in neonatal rat cardiac myocytes. These results show that free polyunsaturated fatty acids can reduce membrane electrical excitability of heart cells and provide an electrophysiological basis for the antiarrhytmic effects of these fatty acids (Kang, 1995).

EICOSAPENTAENOIC ACID is the precursor to the series 3 prostaglandins (PGE 3 ) and also provides a natural approach to lower blood cholesterol and triglycerides. Prostaglandin E3 is directly responsible for making blood platelets less sticky, thus leading to an easier flow of blood throughout our bodies. This natural antithrombotic «anticlotting" effect of EPA has been well researched. This means that EPA is intimately involved in bodily processes that inhibit blood clots, particularly in the small capillaries of the heart (Stefanov, 1997).

DOCOSAHEXAENOIC ACID, an omega-3 long chain polyunsaturated fatty acid, is the building block of human brain tissue. It is the primary structural fatty acid in the gray matter of the brain and retina of the eye. Brain tissue is about $60 \%$ lipid (structural fat, not adipose fat) and about $25 \%$ of that is DHA.

Humans obtain DHA from their diets, initially through the placenta and from breast milk. DHA is essential for brain and eye development and for mental and visual function. Fish provide a rich source of DHA but like humans, fish do not adequately synthesize it and obtain DHA from microalgae.

An expert panel of the World Health Organization has recommended that all infant formula be enriched with this fatty acid. DHA is the most abundant omega-3 long-chain polyunsaturated fatty acid found in breast-milk. Several studies on the development of intelligence in both term and pre-term infants indicate that when all recognized confounding factors (e.g., parental age, IQ, socioeconomic class, child's birth weight, etc.) are accounted for, the children (18 months to 15 years) who were breast-fed had a significantly higher IQ - 2 to 9 points - compared to formula-fed infants.

The brains of Alzheimer's patients show lower levels of DHA and of arachidonic acid than do the brains of healthy geriatric patients and epidemiological research shows a correlation between reduced intake of this fatty acid and the increased incidence of depression and dementia.

DHA also inhibits the effect of dihydropyridine (DHP) agonists and antagonists on $\mathrm{Ca}^{2+}$ channels (Pepe, 1994).

\subsection{Phospholipids}

Phospholipids (PLs) are important structural components of cell membranes. Of all brain and body cells, membranes are the main working surfaces. PLs (phosphatidylserine, phosphatidylcholine, phosphatidylethanolamine and phophatidylinositol, etc.) promote membrane fluidity which is crucial for cellular responsiveness and for processing of nutrients and information by the cell.

With age, the membranes tend to get stiffer and more resistant to the normal movement of molecules. Less movement of molecules means decreased function in brain cells. PLs relax membranes, allowing for more normal function.

Nerve cells especially depend on membranes to carry out their specialized functions. For example, membranes in nerve cells generate the electrical current of a thought, transmit that current along the cell's axon and relay the current from cell to cell. In all of these processes, membrane proteins play key roles, and PLs regulate the activities of such proteins. PLs not only aid in the conduction of nerve impulses, they also help accumulate, store and release nerve transmitter substances, supporting homeostasis in the brain.

PLs may be usefull in the age-related decline in memory and concentration, epilepsy, Parkinson's disease and Alzheimer's disease.

LECITHIN is the chief phospholipid found in bile and is important in keeping the bile in solution and not precipitated out in the form of gallstones. It may also aid in removing cholesterol from arterial walls and increase immunity against viral infections. Lecithin plays an important part in maintaining a healthy nervous system and is found naturally in the myelin sheath, a fatty protective covering for the nerves. It is high in phosphorus and unites with iron, iodine and calcium to give power and vigor to the brain.

A particularly important natural phospholipid is Platelet-Activating Factor (PAF), which resembles a phosphatidylcholine. It activates blood platelets and contributes to diverse biological effects, including thrombosis, inflammatory reactions and allergies (Dewich, 1997).

Lysophosphatidic acid (LPA), formed during mild oxidation of $\mathrm{LDL}$, is an atherothrombogenic molecule, initiating platelet activation and stimulating endothelial cell stress-fiber and gap formation (Siess, 1999).

\subsection{Sphingolipids}

The «sphingosine» backbone of sphingolipids was so named by J.L. Thudichum in 1884 for its enigmatic («Sphinx-like») properties. Research on the involvement of sphingolipids in the signal transduction pathway that mediate cell grown, differentiation, multiple cell functions, and cell death has been rapidly expanding our understanding of these compounds (Merrill, 1997). 
The sphingolipid cycle encompasses a large family of biomolecules which play unique and diverse roles in signal transduction. In a process analogous to the phospholipase C- mediated production of diacylglycerols, sphingomyelinase hydrolyzes sphingomyelin producing ceramide, a second messenger which can stimulate protein phosphatase 2A, MAP kinase and induce apoptosis.

Ceramide is a potent biomolecule with effects in multiple cell signaling pathways. Increases in cellular ceramide levels may lead to cell growth arrest, cell differentiation or programmed cell death (apoptosis) (Dobrowsky, 1998).

Ceramide may be converted, via ceramidase, to sphingosine, which displays a variety of activities, or phosphorylated to ceramide 1-phosphate. Sphingosine can be converted to sphingosine-1-phosphate which is mitogenic and stimulates calcium release from intracellular stores. Inducers of sphingomyelin breakdown and release of sphingoid second messengers include TNF- $\alpha, \gamma$-interferon, IL-1, $1 \alpha, 25$-dihydroxyvitamin $D_{3}$, complement components and diverse forms of cellular stress (Brown, 1998).

Ceramides and sphingosines are molecules widely implicated in cell differentiation and apoptosis. In vitro, they have been shown to be active against several human cancers including non-small-cell lung, breast, renal cell, ovarian and colon cancer, as well as against drug resistant cell lines (Merrill, 1997).

Nichols (1998) has recently reported that Porphyromonas gingivalis synthesizes at least four major ceramides and two of these are selectively adsorbed to diseased tooth surfaces and may penetrate into diseased gingival tissue.

\subsection{Prostaglandins}

The prostaglandins are a group modified C20 fatty acids first isolated from human semen and initially assumed to be secreted by the prostate gland. They are now known to occur widely in animal tissues, but only in tiny amounts.

Prostaglandins are biosynthesized from three essential fatty acids: dihomo-gamma-linolenic acid, arachidonic acid and eicosapentaenoic acid, which yield prostaglandins of the 1-, 2- and 3-series, respectively.

They have been found to exert a wide variety of pharmacological effects on humans and animals. They are active at very low, hormone-like concentrations and can regulate blood pressure, gastric secretions, platelet aggregation and contractions of smooth muscle. (Dewick, 1997; Groenewald, 1997).

Isoprostanes: In 1990, it has been reported the discovery that prostaglandin (PG) F2-like compounds are formed in abundance in vivo by free radical catalyzed peroxidation of arachidonic acid, independent of the cyclooxygenase enzyme (Rokach, 1998). Since these compounds are isomeric to prostaglandin F2 formed by the cyclooxygenase, they have been termed F2-isoprostanes (Roberts, 1999; Morrows, 1999).

\subsection{FAT-OIL VITAMINS}

\subsubsection{Carotenoids}

Carotenoids are red, yellow and orange pigments which are widely distributed in nature.

They contain a conjugated backbone composed of isoprene units, which are usually inverted at the center of the molecule, imparting symmetry. Changes in geometrical configuration about the double bonds result in the existence of many cis and trans isomers (O'Neil, 1992).

Carotenoids absorb light in the 400-500 nm region of the visible spectrum. This physical property imparts the characteristic red/yellow color of the pigments.

Although specific carotenoids have been identified in photosynthetic centers in plants, bird feathers, crustaceans and marigold petals, they are especially abundant in yellow-orange fruits and vegetables and dark green, leafy vegetables (Beecher, 1992). Of the more than 700 naturally occurring carotenoids identified thus far, as many as 50 may be absorbed and metabolized by the human body. To date, only 14 carotenoids have been identified in human serum.

The established efficacy of beta-carotene in quenching singlet oxygen and intercepting deleterious free radicals and reactive oxygen species makes it part of the diverse antioxidant defense system in humans (Ozhogina, 1995). Reactive oxygen species have been implicated in the development of many diseases, including ischemic heart disease, various cancers, cataracts and macular degeneration (Halliwell, 1992). In vitro experiments have also demonstrated that lycopene, alpha-carotene, zeaxanthin, lutein and cryptoxanthin quench singlet oxygen and inhibit lipid peroxidation (Di Mascio, 1989).

Carotenoids are absorbed from the intestine with the aid of dietary fat and incorporated into chylomicrons for transport in the serum. Due to the hydrophobic character, carotenoids are associated with lipid portions of human tissues, cells and membranes. The major serum carotenoids are beta-carotene, alpha-carotene, lutein, zeaxanthin, lycopene and cryptoxanthin. Smaller amounts of polyenes such as phytoene and phytofluene are also present.

BETA-CAROTENE: the all-trans isomer of this carotenoid is the major source of dietary retinoids, due to its high provitamin A activity (Wang, 1998). 
Beta-carotene quenches singlet oxygen, induces gap junction communication and inhibits lipid peroxidation (Zhang, 1991). High serum levels of beta-carotene are correlated with low incidences of cancer in the mouth (Stich, 1991), lung (Stahelin, 1991), breast (Wald, 1984), cervix (Palan, 1991), skin (Ramaswamy, 1990) and stomach (Stahelin, 1991). Beta-caroteno is used for protecting lungs from air pollutants and as lung protection for smokers and ex-smokers.

ALPHA-CAROTENE: this carotenoid is similar to beta-carotene in its biological activity, but quenches singlet oxygen more effectively (Di Mascio, 1989). Alpha-carotene improves gap junction communication, prevents lipid peroxidation and inhibits the formation and uptake of carcinogens in the body (Zhang, 1991). High serum levels have been associated with lower risks of lung cancer. With one half the provitamin A potency of beta-carotene, alpha-carotene also restores normal cell growth and differentiation.

LUTEIN: this xanthophyll exists in the retina. It functions to protect photoreceptor cells from lightgenerated oxygen radicals, and thus plays a key role in preventing advanced macular degeneration (Schalch, 1992). Lutein does not possess provitamin A activity. Zeaxanthin: in addition to lutein, zeaxanthin exists in the retina and confers protection against macular degeneration (Schalch, 1992). Zeaxanthin is also prevalent in ovaries and adipocyte tissue (Kaplan, 1990) This xanthophyll does not possess provitamin A activity. Lutein and zeaxanthin may have protective effects against LDL oxidation (Forman, 1995).

Many epidemiological studies have established an inverse correlation between dietary intake of yellow-orange fruit and dark green, leafy vegetables and the incidence of various cancers, especially those of the mouth, pharynx, larynx, esophagus, lung, stomach, cervix and bladder (Ziegler, 1991; Block, 1992).

\subsubsection{Retinoids}

Vitamin A and its biologically active derivatives, retinal and retinoic acid, together with a large repertoire of synthetic analogues are collectively referred to as retinoids. Vitamin $A_{1}$ (retinol) and vitamin $A_{2}$ (dehydroretinol) are fat-soluble vitaminsfound only in animal products, especially dairy products, eggs and animal livers and kidneys. Fish liver oils (halibut-liver oil and cod-liver oil) are particularly rich sources. They exist as free alcohols or as esters with acetic and palmitic acid (Dewick, 1997).

Naturally occurring retinoids regulate the growth and differentiation of a wide variety of cell types and play a crucial role in the physiology of vision and as morphogenic agents during embryonic development.
Retinoids and their analogues have been evaluated as chemoprevention agents, and also in the management of acute promyelocytic leukaemia (Wiegand, 1998; Evans, 1999).

The synthetic retinoic acids tretinoin (retinoic acid) and isotretinoin (13-cis-retinoic acid) are retinoids that are used as topical or oral teatments for acne vulgaris, reducing levels of dehydroretinol and modifying skin keratinization. Dehydroretinol levels in the skin become markedly elevated in conditions such as eczema and psoriasis (Griffiths, 1999).

\subsubsection{Tocopherols}

Vitamin $\mathrm{E}$ designates the group of compounds (tocol and tocotrienol derivates) which exhibit qualitatively the biological activity of $\alpha$-tocopherol. It is an essential nutrient which must be supplied in the diet. Affortunately, vitamin $\mathrm{E}$ is widespread in our food supply and is found mainly in vegetable oils (such as canola, sunflower, safflower, olive and wheat germ oil), nuts, whole grains and egg yolks. Smaller amounts are found in fruits, vegetables, meats and fish.

Vitamin $E$ is present in all cell membranes, plasma lipoproteins and red blood cells. As the major lipid-soluble chain-breaking antioxidant in humans, it functions to protect DNA, LDL and PUFAs from free radical-induced oxidation. Vitamin $E$ also quenches singlet oxygen. In this regard, d-alpha-tocopherol is the most biologically active isomer (Sies, 1992).

Approximately $40 \%$ of ingested vitamin $E$ is absorbed Long chain dietary triglycerides enhance absorption. The different isomers are also absorbed with different efficiency. Vitamin $E$ and fish oil potentiated the effect of each other (Chen, 1999).

Iron supplements destroy vitamin E. High intakes of vitamin A reduce the uptake of vitamin $E$, whereas high doses of vitamin $E$ can impair the absorption of vitamin $\mathrm{K}$.

The recent attention given to the possible role of vitamine $E$ and carotenoids in the prevention and treatment of a variety of illnesses resulted in segments of the population increasing their consumption of these antioxidants. Once consumed, vitamine $\mathrm{E}$ and carotenoids are thought to follow the same absorptive pathway and may influence each other's absorption, particularly when taken in large doses. These results suggest that concurrent consumption of a large dose of vitamine $\mathrm{E}$ may influence carotenoid bioavailability (Hageman, 1999).

Inverse correlations between serum levels of vitamin $E$ and the incidence of diseases such as arthritis, cancer, cataracts and advanced macular degeneration have been established. The risk of developing coronary diseases such as ischemic heart 
disease (Gey et al., 1991), atherosclerosis and angina pectoris (Riemersma et al., 1991) was shown to be dramatically reduced in individuals with a high vitamin E status. In vitro data suggest that vitamin $\mathrm{E}$ protects against oxidation of low-density lipoproteins and decreases the deposition of atherogenic oxidized low-density lipoprotein in arterial walls (Spencer, 1999). Moreover, the ability to of vitamin $E$ and its derivatives to inhibit mutagenesis and chromosomal damage caused by radiation and chemical damage in in vitro studies has been demonstrated. Additionally, Vitamin $E$ can moderate increases in lipid peroxidation resulting from heavy exercise (Kumar, 1992).

The use of the antioxidant supplements, vitamin $\mathrm{E}$ along with vitamin $\mathrm{C}$, may reduce the risk of allcause and coronary heart disease mortality (Spencer, 1999).

Lipid-soluble antioxidants are important to health and diagnostic medicine. Free radicals have also been implicated in causing mutations in cells that may lead to cancer. Some studies have found a link between low blood levels of these substances with increased risk of certain types of cancer. Dietary carotenoids, retinoids and tocopherols have an impact on health and are associated with reduced risk of developing various cancers and other diseases. Many epidemiological studies have established inverse correlations between serum levels of carotenoids, tocopherols and retinol and the incidence of various cancers (mouth (Gridley, 1990; Stich, 1991), pharynx (Temple, 1988; Gridley, 1990; Stahelin, 1991), larynx (Temple, 1988; Stahelin, 1991), esophagus (Temple, 1988; Stahelin, 1991), stomach (Stahelin, 1984 and 1991), lung (Connet, 1989; Le Gardeur, 1990), cervix (Palan, 1991); breast (Wald, 1984); gastrointestinal tract (Knekt, 1988a), colon (Stahelin, 1984), reproductive organs (Knekt, 1988b), bladder (Helzlsouer, 1989), prostate (Hsing, 1990)) and other diseases in humans (cataracts (Shambhu, 1991; Jacques, 1991), advanced macular degeneration (Schalch, 1992) and heart disease (Gey, 1991; Stampfer, 1993; Rimm, 1993)).

\section{REFERENCES}

Ahl, P.L., Bhatia, S.K., Meers, P., Roberts, P., Stevens, R., Dause, R., Perkins, W.R. and Janoff, A.S. (1997) Enhancement of the in vivo circulation lifetime of L-adistearoylphosphatidylcholine liposomes: importance of liposomal aggregation versus complement opsonization. Biochim. Biophys. Acta, 1329, 370-382.

Ako, H., Okuda, D. and Gray, D. (1995) Healthful new oil from macadamia nuts. Nutrition, 11, 286-288.

Andersen, K.E. and Nielsen, R. (1984) Lipstick dermatitis related to castor oil. Contact Dermatitis, 11, 253-254.

Anonymous (1986) Nutrition classics. The Lancet, Vol. I for 1971: Plasma lipid and lipoprotein pattern in Greenlandic
West-Coast Eskimos. By H.O. Bang, J. Dyerberg, Aase Brondum Nielsen. Nutr. Rev. 44, 143-146.

Arco, J. del, Arruza, M.A., Diego, M. de, Fuertes, A., Garmendía, G., González, M., Ibañez, D., Melero, R., Monje, I., Ordieres, E., Torre, M.A. and Urruticoechea, A. (1997) Formulación Magistral de Medicamentos, 4a ed., Ed. Colegio Oficial de Farmacéuticos de Vizcaya, Bilbao.

Asai, Y. and Watanabe, S. (1999) Interaction of soybean oil with phosphatidylcholine and their formation of small dispersed particles. Drug Dev. Ind. Pharm. 25, 643-650.

Baddour, L.M. (1997) Life-threatening fungal infections in patients with diabetes mellitus: treatment with amphotericin B lipid complex. Infect. Dis. Clin. Pract. 6, 537-542.

Balasubramaniam, R.P., Bennett, M.J., Aberle, A.M., Malone, J.G., Nantz, M.H. and Malone, R.W. (1996) Structural and functional analysis of cationic transfection lipids: the hydrophobic domain. Gene Ther. 3, 163-172.

Barre, D.E. and Holub, B.J. (1992) The effect of borage oil consumption on the composition of individual phospholipids in human platelets. Lipids, 27, 315-320.

Batist, G., Winer, E., Navari, R., Rovira, D. and Azarnia, N. (1998) Decreased cardiac toxicity by TLC D-99 (liposome encapsulated doxorubicin) vs. doxorubicin in a randomized trial of metastatic breast carcinoma (MBC). Proc. Am. Soc. Clin. Oncol. 17, 115.

Beecher, G.R. and Khackik, F. (1992) Qualitative relationship of dietary and plasma carotenoids in human beings. An. N. Y. Acad. Sci. 669, 320-321.

Belotserkovets, V.M., Mukhtarov, E.I., Sidorov N.N. and Shevtsov, V.I. (1998) Vitamin F with the balanced ratio of omega-3 / omega-6 fatty acids. III International Scientific-Practical Conference «Biologically Active Substances: New Technologies and Products in Cosmetics", Moscow.

Blobe, G.C., Khan, W.A. and Hannun, Y.A. (1995) Protein kinase C: cellular target of the second messenger arachidonic acid? Prostaglandins Leukot. Essent. Fatty Acids, 52, 129-135.

Block, G. (1992) Fruit, vegetables and cancer prevention: $A$ review of the epidemiological evidence. Nutrition and Cancer, 18, 1-29.

Bocan, T.M. (1998) Animal models of atherosclerosis and interpretation of drug intervention studies. Curr. Pharm. Des. 4, 37-52.

Bordier, C.G., Sellier, N., Foucault, A.P. and Le Goffic, F. (1996) Purification and characterization of deep sea shark Centrophorum squamosus liver oil 1-O-alkylglycerol ether lipids. Lipids, 31, 521 - 528.

Brown, R.E. (1998) Sphingolipid organization in biomembranes: what physical studies of model membranes reveal. J. Cell Science, 111, 1-9.

Chen, M.F., Hsu, H.C., Liau, C.S. and Lee, Y.T. (1999) The role of vitamin $\mathrm{E}$ on the anti-atherosclerotic effect of fish oil in diet-induced hypercholesterolemic rabbits. Prostaglandins \& Other Lipid Mediat., 57, 99-111.

Connet, J.E., Kuller, L.H., Kjelsberg, M.O., Polk, B.F., Collins, G., Rider, A. and Hulley, S.B. (1989) Relationship between carotenoids and cancer. The Multiple Risk Factor Intervention Trial (MRFIT) Study. Cancer, 64, 126-134. 
Dave, V.K., Roberts, M.M. and Butterfield, W. (1987) Pityriasis versicolor and sunscreens containing coconut oil. Lancet, 8560, 685-686.

Delaveau, P. and Hotellier, F. (1971) Huiles a interet pharmaceutique, dietetique et cosmetologique. I. Mai's, soja, tournesol. Ann. Pharm. Fr., 29, 399-412.

Dewick, P.M. (1997) Medicinal natural products: a biosynthetic aproach. John Wiley \& Sons, Chichester.

Di Mascio, P., Kaiser, S. and Sies, H. (1989) Lycopene as the most efficient biological carotenoid singlet oxygen quencher. Arch. Biochem. Biophys. 274, 532-538.

Dix, S.P. and Wingard, J.R. (1996) Amphotericin B lipid complex: review of safety, pharmacokinetics and efficacy. Drugs Today, 32, 411-416.

Dobrowsky, R.T. and Carter, B.D. Coupling of the p75 neurotrophin receptor to sphingolipid signaling. Ann. N. Y. Acad. Sci. 845, 32-45.

Dupont, J., White, P.J., Johnston, K.M., Heggtveit, H.A., McDonald, B.E., Grundy, S.M. and Bonanome, A. (1989) Food safety and health effects of canola oil. $J$. Am. Coll. Nutr. 8, 360-375.

Esquisábel, A., Hernández, R.M., Igartua, M., Gascón, A.R., Calvo, B. and Pedraz, J.L. (1997) Production of BCG alginate-PLL microcapsules by emulsification/ internal gelation. J. Microencapsul., 14, 627-638.

Estévez-González, M.D., Saavedra-Santana, P. and Betancor-León, P. (1998) Reduction of serum cholesterol and low-density lipoprotein cholesterol levels in a juvenile population after isocaloric substitution of whole milk with a milk preparation (skimmed milk enriched with oleic acid). J. Pediatr. 132, 85-89.

Evans, T.R. and Kaye, S.B. (1999) Retinoids: present role and future potential. Br. J. Cancer, 80, 1-8.

Fan, Y.Y. and Chapkin, R.S. (1998) Importance of dietary gamma-linolenic acid in human health and nutrition. $J$. Nutr. 128, 1411-1414.

Forman, M.R., Beecher, G.R., Lanza, E., Reichman, M.E., Graubard, B.I., Campbell, W.S., Marr, T., Yong, L.C., Judd, J.T. and Taylor, P.R. (1995) Effect of alcohol consumption on plasma carotenoid concentrations in premenopausal women: a controlled dietary study. Am. J. Clin. Nutr. 62, 131-135.

Fromtling, R.A. (1996) Experimental and clinical pharmacokinetics of amphotericin B lipid complex. Drugs Today, 32, 403-409.

Gámez-Meza, N., Higuera-Ciapara, I., Calderón de la Barca, A.M., Vázquez-Moreno, L., Noriega-Rodríguez, J. and Angulo-Guerrero, O. (1999) Seasonal Variation in the Fatty Acid Composition and Quality of Sardine Oil from Sardinops sagax caeruleus of the Gulf of California, Lipids, 34, 639-642.

Gey, K.F., Puska, P., Jordan, P. and Moser, U.K. (1991) Inverse correlation between plasma vitamin $E$ and mortality from ischemic heart disease in cross-cultural epidemiology. Am. J. Clin. Nutr. 53, 326S-334S.

Ghosh, P., Whitehouse, M., Dawson, M. and Turner, A.G. (1996) U.S. Patent 5,431,924.

Girgis, A.Y., Abd El-Aziz N.M. and Abd El-Salam, S.M. (1998) Physical and chemical characteristics of toilet soap made from apricot kernel oil and palm stearin. Grasas Aceites, 49, 434-439.

Griffiths, C.E. (1999) Drug treatment of photoaged skin. Drugs Aging, 14, 289-301.
Gridley, G., McLaughlin, J.K., Block, G., Blot, W.J., Winn, D.M., Greenberg, R.S., Schoenberg, J.B., PrestonMartin, S., Austin, D.F. and Fraumeni, J.F. Jr (1990) Diet and oral and pharyngeal cancer among blacks. Nutr. Cancer, 14, 219-225.

Groenewald, E.G. (1997) Prostaglandins and related substances in plants. The Botanical review, 63, 199-220.

Hageman, S.H., She, L., Furr, H.C. and Clark, R.M. (1999) Excess vitamin $E$ decreases canthaxanthin absorption in the rat. Lipids, 34, 627-631.

Halliwell, B., Gutteridge, J.M. and Cross, C.E. (1992) Free radicals, antioxidants, and human disease: where are we now? J. Lab. Clin. Med., 119, 598-620.

Harris, W.S. (1999) Nonpharmacologic treatment of hypertriglyceridemia: focus on fish oils. Clin. Cardiol. 22, 1140-1143.

Hassam-El-Mallah, M., Murui, T. and El-Shami, S. (1999) New trends in determining the authenticity of corn oil. Grasas Aceites, 50, 7-15.

Helme, J.P., Chazan, J.B. and Perrin, J.L. (1992) Les antioxidants. In Actifs and additifs en cosmetologie (Ed. Martini, M.C. and Seiller, M.) Technique \& Documentation, Paris.

HelzIsouer, K.J., Comstock, G.W. and Morris, J.S. (1989) Selenium, lycopene, alpha-tocopherol, beta-carotene, retinol, and subsequent bladder cancer. Cancer Res., 49, 6144-6148.

Henz, B.M., Jablonska, S., Van De Kerkhof, P.C., Stingl, G., Blaszczyk, M., Vandervalk, P.G., Veenhuizen, R., Muggli, R. and Raederstorff, D. (1999) Double-blind, multicentre analysis of the efficacy of borage oil in patients with atopic eczema. Br. J. Dermatol. 140, 685688.

Hiemenz, J.W. and Walsh, T.J. (1996) Lipid formulations of amphotericin B: recent progress and future directions. Clin. Infect. Dis. 22, S133-S144.

Hodgson, C.P. and Solaiman, F. (1996) Virosomes: cationic liposomes enhance retroviral transduction. Nat. Biotechnol. 14, 339-342.

Hsing, A.W., Comstock, G.W., Abbey, H. and Polk, B.F. (1990) Serologic precursors of cancer. Retinol, carotenoids, and tocopherol and risk of prostate cancer. J. Nat. Cancer Inst. 82, 941-946.

Huang, F.C., Ju, Y.H. and Chiang, J.C. (1999) GammaLinolenic acid-rich triacylglycerols derived from borage oil via Lipase-catalyzed reactions. JAOCS, 76, 833-837.

Huang, X.P., Pi, Y.Q., Lokuta, A.J., Greaser, M.L. and Walker, J.W. (1997). Arachidonic acid stimulates protein kinase C-(epsilon) redistribution in heart cells. J. Cell Sci., 110, 1625-1634.

Huertas, J.R., Martínez-Velasco, E., Ibáñez, S., LópezFrías, M., Ochoa, J.J., Quiles, J., Parenti, G., Mataix, J. and Lenaz, G. (1999) Virgin olive oil and coenzyme Q10 protect heart mitochondria from peroxidative damage during aging. Biofactors, 9, 337-343.

Innis, S.M. and Dyer, R.A. (1999) Dietary canola oils alters hematological indices and blood lipids in neonatal piglets fed formula. J. Nutr. 129, 1261-1268.

Jacques, P.F and Chylack, L.T. (1991) Epidemiological evidence of a role for the antioxidant vitamins and carotenoids in cataract prevention. Am. J. Clin. Nutr. 53, 352S-355S.

Janoff, A.S., Perkins, W.R., Saletan, S.L. and Swenson, C.E. (1993) Amphotericin B lipid complex: a molecular 
rationale for the attenuation of amphotericin $B$ related toxicities. J. Liposome Res. 3, 451-471.

Jones, M.N., Song, Y.H., Kaszuba, M. and Reboiras, M.D. (1997) The interaction of phospholipid liposomes with bacteria and their use in the delivery of bactericides. J. Drug Target. 5, 25-34.

Kang, J.X., Xiao, Y.F. and Leaf, A. (1995) Free, longchain, polyunsaturated fatty acids reduce membrane electrical excitability in neonatal rat cardiac myocytes. Proc. Natl. Acad. Sci. U S A, 92, 3997-4001.

Kaplan, L.A., Lau, J.M. and Stein, E.A. (1990) Carotenoid composition, concentrations, and relationships in various human organs. Clin. Physiol. Biochem. 8, 1-10.

Kaplun, A.P., Le Bang, S. and Oksinoyd, O.E. (1998) Ceramides as a component of cosmetic products. III International Scientific-Practical Conference «Biologically Active Substances: New Technologies and Products in Cosmetics", Moscow.

Kim, D. (1992) A mechanosensitive K+ channel in heart cells. Activation by arachidonic acid. J. Gen. Physiol. 100, 1021-1040.

Knekt, P., Aromaa, A., Maatela, J., Alfthan, G., Aaran, R.K., Teppo, L. and Hakama, M. (1988a) Serum vitamin $\mathrm{E}$, serum selenium and the risk of gastrointestinal cancer. Int. J. Cancer, 42, 846-850.

Knekt, P. (1988b) Serum vitamin E level and the risk of female cancers. Int. J. Epidem. 17, 281-288.

Kruth, H.S. (1997) Cholesterol deposition in atherosclerotic lesions. Subcell. Biochem. 28, 319362.

Kumar, C.T., Reddy, V.K., Prasad, M., Thyagaraju, K. and Reddanna, P. (1992) Dietary supplementation of vitamin $\mathrm{E}$ protects heart tissue from exercise-induced oxidant stress. Mol. Cell. Biochem. 111, 109-115.

Kusmina, S.M., Mukhtarov, E.I. and Shevtsov, V.I. (1998) Lypofundin cosmetic-new biologically active preparation based on natural lipids. III International Scientific-Practical Conference «Biologically Active Substances: New Technologies and Products in Cosmetics", Moscow.

Lazos, E.S., Tsaknis, J. and Lalas, S. (1998) Characteristic and composition of tomato seed oil. Grasas Aceites, 49, 440-445.

Leaf, A. and Kang, J.X. (1996) Prevention of cardiac sudden death by N-3 fatty acids: a review of the evidence. J. Intern. Med. 240, 5-12.

LeGardeur, B.Y., López, A. and Johnson, W.D. (1990) A case-control study of serum vitamins $A, E$, and $C$ in lung cancer patients. Nutr. Cancer, 14 133-140.

Li, S., Rizzo, M.A., Bhattacharya, S. and Huang, L. (1998) Characterization of cationic lipid-protamine-DNA (LPD) complexes for intravenous gene delivery. Gene Ther. 5, 930-937.

Lichtenstein, A.H., Kennedy, E., Barrier, P., Danford, D., Ernst, N.D., Grundy, S.M., Leveille, G.A., Van Horn, L., Williams, C.L. and Booth, S.L. (1998) Dietary fat consumption and health. Nutr. Rev. 56, S3-S28.

Loftsson, T., Petersen, D.S., Le Goffic, F. and Olafsson, J.H. (1997) Unsaturated glycerol monoethers as novel skin penetration enhancers. Pharmazie, 52, 463-465.

Lundberg, W.O. (1984) Lipidology. In Handbook of chromatography. Lipids (Ed. Mangold, H.K.).CRC Press Inc., Vol I, Boca Raton, 1-27.
Madrid, A., Cenzano, I. and Vicente, J.M. (1997) Manual de Aceites y Grasas Comestibles, AMV Ediciones, Madrid.

Maesen, F.P., Lamers, J.H. and van der Tweel, J.G. (1985) Bronchiolo-alveolar carcinoma after inhalation of vegetable oil through a tracheal cannula. Eur. J. Respir. Dis. 67, 136-138.

Maestri, M., Labuckas, D.O., Guzmán, C.A. and Giorda, L.M. (1998) Correlation between seed size, protein and oil contents, and fatty acid composition in soybean genotypes. Grasas Aceites, 49, 450-453.

Mancuso, P., Whelan, J., DeMichele, S.J., Snider, C.C., Guszcza, J.A. and Karlstad, M.D. (1997) Dietary fish oil and fish and borage oil supress intrapulmonary proinflammatory eicosanoid biosynthesis and attenuate pulmonary neutrophil accumulation in endotoxic rats. Crit. Care Med. 25, 1198-1206.

Merrill, A.H. Jr., Schmeiz, E.M., Dillehay, D.L., Spiegel, S., Shayaman, J.A., Schroeder, J.J., Riley, R.T., Voss, K.A. and Wang, E. (1997) Sphingolipids: the enigmatic lipid class: biochemistry, physiology, and pathophysiology. Toxicology and applied pharmacology, 142, 208-225.

Millet, J. (1992) Matières premières produites par l'abeille. In Actifs \& additifs en cosmétologie (Ed. Martini, M.C. and Seiller, M.), Technique \& Documentation - Lavoisier, Paris.

Montousse, C., Pruvost, M., Rodríguez, F. and Brossard, C. (1999) Extrusion-spheronization manufacture of Gelucire matrix beads. Drug Dev. Ind. Pharm. 25, 7580.

Morgan, T.M., Reed, B.L. and Finnin, B.C. (1998) Enhanced skin permeation of sex hormones with novel topical spray vehicles. J. Pharm. Sci. 87, 1213-1218.

Morrow, J.D., Chen, Y. and Brame, C.J. (1999) Yang The isoprostanes: unique prostaglandin-like products of free-radical-initiated lipid peroxidation. Drug Metab. Rev. 31, 117-139.

Moureaux, P. (1995) Les traitements locaux en dermatologie. SO - Allerg Immunol (Paris), 27, 200-205.

Muriana, F.J.G. and Ruiz-Gutiérrez, V. (1998) El aceite de oliva virgen y la distribución y movimiento transmembrana del colesterol en la membrana de eritrocito humano, Grasas Aceites, 49, 139-150.

Neff, W.E. and List, G.R. (1999) Oxidative Stability of Natural and Randomized High-Palmitic- and High-Stearic-Acid Oils from Genetically Modified Soybean Varieties, JAOCS, 76, 825-831.

Newman, W.P., Middaugh, J.P., Propst, M.T. and Rogers, D.R. (1993) Atherosclerosis in Alaska Natives and non-natives. Lancet. 341, 1056-1057.

Nichols, F.C. (1998) Novel ceramides recovered from Porphyromonas gingivalis: relationship to adult periodontitis. J. Lipid Res. 39, 2360-2372.

Nieto, S., Córdoba, A.M., Sanhueza, J. and Valenzuela, A. (1997) Obtention of highly purified fractions of eicosapentaenoic acid and docosahexaenoic acid from sardine oil by silver-resin chromatography: A semipreparative procedure. Grasas Aceites, 48, 197-199.

O'Neil, C.A. and Schwartz, S.J. (1992) Chromatographic analysis of cis/trans carotenoid isomers. Journal of Chromatography, 624, 235-252.

Ostro, M.J. and Cullis, P.R. (1989) Use of liposomes as injectable-drug delivery systems. Am. J. Hosp. Pharm. 46, 1576-1587. 
Ostro, M.J. (1992) Drug delivery via liposomes. Drug Ther. 1, 61-65.

Ozhogina, O.A. and Kasaikina, O.T. (1995) Betalphacarotene as an interceptor of free radicals. Free Radical Biology and Medicine, 19, 575-581.

Palan, P.R., Romney, S.L., Vermund, S.H., Mikhail, M.G. and Basu, J. (1989) Effects of smoking and oral contraception on plasma beta-carotene levels in healthy women. Am. J. Obstet. Gynecol. 161, 881-885.

Palan, P.R., Mikhail, M.S., Basu, J. and Romney, S.L. (1991) Plasma levels of antioxidant beta-carotene and alpha-tocopherol in uterine cervix dysplasias and cancer. Nutr. Cancer, 15, 13-20.

Pamuk, E.R., Byers, T., Coates, R.J., Vann, J.W., Sowell, A.L., Gunter, E.W. and Glass, D. (1994) Effect of smoking on serum nutrient concentrations in AfricanAmerican women. Am. J. Clin. Nutr. 59, 891-895.

Parks, L.W., Dotson, W.D., Shianna, K.V., Leak, F.W. and Crowley, J.W. (1998) Aspects of the regulation, metabolism and functions of sterols in fungi. 13 th International Symposium on Plant Lipids, Sevilla.

Pepe, S., Bogdanov, K., Hallaq, H., Spurgeon, H., Leaf, A. and Lakatta, E. (1994) Omega 3 polyunsaturated fatty acid modulates dihydropyridine effects on L-type $\mathrm{Ca} 2+$ channels, cytosolic $\mathrm{Ca} 2+$, and contraction in adult rat cardiac myocytes. Proc. Natl. Acad. Sci. 91, 8832-8836.

Pecquet, C., Leynadier, F. and Saiag, P. (1998) Immediate hypersensibility to sesame in foods and cosmetics. Contact Dermatitis, 39, 313.

Pons, L. and Parra, J.L. (1995) Ciencia Cosmética. Ed. Consejo General de Colegios Oficiales de Farmacéuticos de España, Madrid.

Ponte, E., Cafagna, D. and Balbi, M. (1997) Patologia cardiovascolare ed acidi grassi omega-3. Minerva Med. 88, 343-353.

Poschl, J.M., Paul, K., Leichsenring, M., Han, S.R., Pfisterer, M., Bremer, H.J. and Linderkamp, O. (1999) Effects of dietary supplementation of saturated fatty acids and of $n-6$ or $n-3$ polyunsaturated fatty acids on plasma and red blood cell membrane phospholipids and deformability in weanling guinea pigs. Lipids, 34, 467-473.

Puerta de la, R., Maestro-Durán, R. and Ruiz-Gutiérrez, V. (1997) Actividad farmacológica de la fracción de esteroles y alcoholes triterpénicos aislada del aceite de oliva virgen. Grasas Aceites, 48, 93-95.

Pugliese, P.T., Jordan, K., Cederberg, H. and Brohult, J. (1998) Some biological actions of alkylglycerols from shark liver oil. J. Altern. Complement. Med. 4, 87-99.

Ramaswamy, P.G., Krishnamoorthy, L., Rao, V.R. and Bhargava, M.K. (1990) Vitamin and provitamin A levels in epithelial cancers: a preliminary study. Nutr. Cancer, 14, 273-276.

Riemersma, R.A., Wood, D.A., Macintyre, C.C., Elton, R.A., Gey, K.F. and Oliver, M.F. (1991) Risk of angina pectoris and plasma concentrations of vitamins $A, C$, and $\mathrm{E}$ and carotene. Lancet, 337, 1-5.

Rimm, E.B., Stampfer, M.J., Ascherio, A., Giovannucci, E., Colditz, G.A. and Willett, W.C. (1993) Vitamin E consumption and the risk of coronary heart disease in men. N. Engl. J. Med. 328, 1450-1456.

Roberts, L.J., Brame, C.J., Chen, Y. and Morrow, J.D. (1999) Novel eicosanoids. Isoprostanes and related compounds. Methods Mol. Biol., 120, 257-285.
Rokach, J., Khanapure, S.P., Hwang, S.W., Adiyaman, M., Lawson, J.A. and Fitzgerald, G.A. (1998) The Isoprostanes: A Perspective. Prostaglandins \& Other Lipid Mediat., 54, 823-851.

Rotheim, P. (1997) Lipids: new technologies, applications and markets. Business Communications Company, Norwalk.

Ruiz-Gutiérrez, V., Muriana, F.J.G. and Villar, J. (1998) El aceite de oliva vírgen y las enfermedades cardiovasculares. Perfil lipídico en plasma y composición lipídica de la membrana de eritrocito humano. Grasas Aceites, 49, 9-29.

Sadi, A.M., Toda, T., Oku, H. and Hokama, S. (1996) Dietary effects of corn oil, oleic acid, perilla oil, and evening [corrected] primrose oil on plasma and hepatic lipid level and atherosclerosis in Japanese quail. Exp. Anim., 45, 55-62.

Schalch, W. (1992) Carotenoids in the retina - A review of their possible role in preventing or limiting damage caused by light and oxygen. EXS (Supplementum to Experientia), 62, 280-298.

Serhan, C.N. (1997) Lipoxins and Novel Aspirin-Triggered 15-epi-Lipoxins (ATL): A Jungle of Cell-Cell Interactions or a Therapeutic Opportunity? Prostaglandins \& Other Lipid Mediat., 53, 107-137.

Shambhu, V.D. (1991) Scientific basis for medical therapy of cataracts by antioxidants. Am. J. Clin. Nutr., 53, 335S-345S.

Shimada, Y., Watanabe, Y., Samukawa, T., Sugihara, A., Noda, H., Fukuda, $H$. and Tominaga, Y. (1999) Conversion of vegetable oil to biodiesel using immobilized Candida antarctica lipase. JAOCS, 76, 789-793.

Sies, H., Stahl, W. and Sundquist, A.R. (1992) Antioxidant functions of vitamins. Vitamins $\mathrm{E}$ and $\mathrm{C}$, betacarotene, and other carotenoids. Ann. N. Y. Acad. Sci., 669, 7-20.

Siess, W., Zangl, K.J., Essler, M., Bauer, M., Brandl, R., Corrinth, C., Bittman, R., Tigyi, G. and Aepfelbacher, M. (1999) Lysophosphatidic acid mediates the rapid activation of platelets and endothelial cells by mildly oxidized low density lipoprotein and accumulates in human atherosclerotic lesions. Proc. Natl. Acad. Sci., 96, 6931-6936.

Smolinske, S.C. (1992) Handbook of food, drug and cosmetic excipients. CRS Press, Boca Raton.

Spencer, A.P., Carson, D.S. and Crouch, M.A. (1999) Vitamin $\mathrm{E}$ and coronary artery disease. Arch. Intern. Med., 159, 1313-1320.

Stahelin, H.B., Rosel, F., Buess, E. and Brubacher, G. (1984) Cancer, vitamins, and plasma lipids: prospective Basel study. J. Natl. Cancer Inst., 73, 1463-1468.

Stahelin, H.B., Gey, K.F., Eichholzer, M. and Ludin, E. (1991) Beta-carotene and cancer prevention: the Basel Study. Am. J. Clin. Nutr., 53, 265S-269S.

Stampfer, M.J., Hennekens, C.H., Manson, J.E., Colditz, G.A., Rosner, B. and Willett, W.C. (1993) Vitamin E consumption and the risk of coronary disease in women. N. Engl. J. Med., 328, 1444-1449.

Stefanov, K., Seizova, K., Georgieva, G., Zlatanova, S., Kuleva, L. and Popov, S. (1997) Preparation of polyunsaturated fatty acid concentrates from the liver oil of dogfish (Squalus acanthias) from the Black Sea. Grasas Aceites, 48, 141-143. 
Stern, A. and Wuthrich, B. (1998) Non-IgE-mediated anaphylaxis to sesame. Allergy, 53, 325-326.

Stich, H.F., Mathew, B., Sankaranarayanan, R. and Nair, M.K. (1991) Remission of precancerous lesions in the oral cavity of tobacco chewers and maintenance of the protective effect of beta-carotene or vitamin A. Am. J. Clin. Nutr., 53, 298S-304S.

Tella, A. (1979) Preliminary studies on nasal descongestant activity from the seed of the shea butter tree, Butyrospermum parkii. Br. J. Clin. Pharm., 134, 215-220.

Temple, N.J. and Basu, T.K. (1988) Does beta-carotene prevent cancer? A critical appraisal. Nutrition Research, 8, 685-701.

Ten Wolde, S., Engels, F., Miltenburg, A.M., Juijpers, E.A., Struijk-Wielinga, G.I. and Dijmans, B.A. (1997) Sesame oil in injectable gold: two drugs in one? Br. J. Rheumatol., 36, 1012-1015.

Tisnes, P. and Moulet-Scott, A.M. (1992) Monographies des principales plantes utilisées en cosmétologie. In Actifs \& additifs en cosmétologie (Ed. Martini, M.C. and Seiller, M.), Technique \& Documentation - Lavoisier, Paris.

Tolleson, A. and Frithz, A. (1993) Borage oil, an effective new treatment for infantile seborrhoeic dermatitis. $\mathrm{Br}$. J. Dermatol., 129, 95.

Truswell, A.S. and Choudhury, N. (1998) Monounsatured oils do not all have the same effect on plasma cholesterol. Human Nutrition Unit, 52, 312-315.

Tsaknis, J., Lalas, S. and Lazos, E.S. (1997) Characterization of crude and purified pumpkin seed oil. Grasas Aceites, 48, 267-272.

Turco, S. and King, R.E. (1987) Sterile dosage forms. $3^{\text {rd }}$ edit., Lea \& Febiger, Philadelphia.

Wakelin, S.H., Harris, A.J. and Shaw, S. (1996) Contact dermatitis from castor oil in zinc and castor oil cream. Contact Dermatitis, 35, 259.

Wald, N.J., Boreham, J., Hayward, J.L. and Bulbrook, R.D. (1984) Plasma retinol, beta-carotene and vitamin $E$ levels in relation to the future risk of breast cancer. Br. J. Cancer, 49, 321-324.
Wang, X.D. and Krinsky, N.I. (1998) The bioconversion of beta-carotene into retinoids. Subcell. Biochem., 30, 159-180.

Wantke, F., Hemmer, W., Gotz, M. and Jarisch, R. (1996) Contact dermatitis from jojoba oil and myristyl lactate/maleated soybean oil. Contact Dermatitis, 34, 71-72.

Weber, C., Erl, W., Weber, K.S. and Weber, P.C. (1999) Effects of oxidized low density lipoprotein, lipid mediators and statins on vascular cell interactions. Clin. Chem. Lab. Med., 37, 243-251.

Wiegand, U.W., Hartmann, S. and Hummler, H. (1998) Safety of vitamin A: recent results. Int. J. Vitam. Nutr. Res., 68, 411-416.

Wilson, R., Van Schie, B.J. and Howes, D. (1998) Overview of the preparation, use and biological studies on polyglycerol polyricinoleate. Food Chem. Toxicol., 36, 711-718.

Wisniak, J. (1977) Jojoba oil and derivatives. Prog. Chem. Fats Oter Lipids, 15, 167-218.

Wolf, R. (1996) The lanolin paradox. Dermatology, 192, 198-202.

Zemtsov, A., Gaddis, M. and Montalvo-Lugo, V.M. (1996) Moisturizing and cosmetic properties of emu oil: a pilot double blind study. Australas. J. Dermatol., 37, 159161.

Zhang, L.X., Cooney, R.V. and Bertram, J.S. (1991) Carotenoids enhance gap junctional communication and inhibit lipid peroxidation in $\mathrm{C} 3 \mathrm{H} / 10 \mathrm{~T} 1 / 2$ cells: relationship to their cancer chemopreventive action. Carcinogenesis, 12, 2109-2114.

Ziegler, R.G. (1991) Vegetables, fruits and carotenoids and the risk of cancer. American Journal of Clinical Nutrition, 53, 251S-259S.

Zuanich, J., Janshekar, H. and Yoshida, Y. (1998) Fats and oils industry overview. SRI Consulting, Menlo Park.

Zuidam, N.J. and Barenholz, Y. (1999) Characterization of DNA-lipid complexes commonly used for gene delivery. Int. J. Pharm., 183, 43-46. 